\title{
The Joint and Survivorship Bank Account- A Concept Without a Name ${ }^{\dagger}$
}

\section{Donald Kepner*}

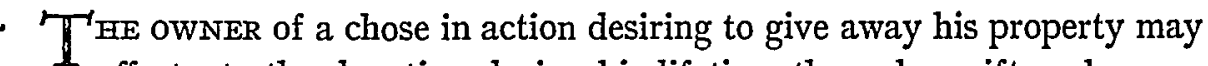
effectuate the donation during his lifetime through a gift or he may provide for a gratuitous transfer effective upon his death. If he pursues the former course the donor must relinquish all dominion over the subject matter of his benefaction. If he follows the latter he retains control but at the expense of complying with the technicalities involved in the law of wills, and at the cost of subjecting the beneficiary to the delay and inconvenience of probate.

To avoid the above mentioned disadvantages donors have seized upon the device of transferring property through the medium of joint and survivorship bank accounts. The account is opened in the name of the depositor and the donee and according to the terms of the deposit is payable to either or the survivor. During his lifetime the donor uses any of the funds that he may need. Upon the depositor's death the donee withdraws the balance which he keeps for his own use free from the claims of the depositor's estate. By this technique the depositor is able to do what heretofore the law never permitted; namely, make a gift without relinquishing control of the subject matter of the benefaction.

If considered in the light of the technical law of gifts the power of the donor to withdraw all of the funds invalidates the entire gift. While it is true that a testator may revoke a will during his lifetime, and while in many instances a settlor may terminate a trust, the right to revoke a gift is not accorded to the donor who makes an inter vivos gratuitous transfer of his property.

There are rather obvious reasons why a donor may want to retain control of the subject matter of the gift. In the first instance he may not desire to surrender all control over the deposit because misfortune may make it necessary that he use the funds for his own maintenance, or because a change in circumstances may make it desirable that he change beneficiaries.

Secondly, he may avoid disposing of all of his property by will not only because of the initial formalities but also because he cannot change the will without duplicating the formalities that he found inconvement in the first

$\uparrow$ This article is based on material submitted in partial satisfaction of the requirements of the J.S.D. degree, New York University.

* Professor of Law, South Jersey Division, Rutgers University. 
case. It may be neither convenient nor desirable to call in an attorney to make a change in his testamentary plan every time the depositor's circumstances change, if his principal assets are funds deposited in a bank.

A third reason may be found in the fact that the probate of a will always involves some delay. The average American family does not keep a great deal of cash on the premises. A joint account will make funds immediately available to the donee, for the contract executed by the depositor authorizes the bank to pay to either of the parties until the amount on deposit is exhausted. Notwithstanding that the tax laws may tie up payment of a portion of the account, some of the funds are usually subject to the survivor's power to withdraw.

But whatever the depositor's reasons when he opens an account in joint form, in accordance with the statute regulating joint accounts and pursuant to the regulations of the bank, he initiates a chain of events that may culminate in litigation following the depositor's death to determine who is entitled to the funds. On the one hand the depositor has not complied with any of the traditional forms of transmitting his property, while on the other hand he manifests an intent to give the balance in the account to the survivor. Such a litigation raises a perplexing problem for the courts. Tribunals pride themselves on their ability to ascertain the transferor's intention when the distribution of property is involved, but when the donor departs from the traditional forms of transferring property courts are placed in a dilemma of trying to effectuate the donor's intention, and at the same time making the transfer conform with one of the recognized means. Sometimes the two cannot be reconciled.

The history of the development of the law of joint bank accounts is a story of courts trying to make this transaction fit into the accepted molds. The result of this conflict has been twofold. The depositor's intention has prevailed, for in almost every jurisdiction it is possible for an individual to make a gift of the balance remaining in the joint account, although the depositor has the power to withdraw all of the funds during his lifetime. The second result is the creation of a new concept which governs the transfer of property in this manner.

THEORIES APPLIED TO DETERMINE THE INTENTION OF THE DEPOSITOR

\section{In General}

To gauge the validity of a voluntary transfer effected through the creation of joint bank accounts courts have applied the law of gifts, trusts, joint tenancies and contracts. In a few instances tribunals have recognized that the transaction does not properly fit into any of the foregoing methods for disposing of property, and have insisted that this is a new technique for 
making gifts. ${ }^{1}$ As this analysis has been shared by the legislatures in some jurisdictions, we have a legislative recognition that property may be donated in this manner without the necessity of complying with the common law requisites that are necessary in the case of a gift, trust, joint tenancy or contract.

\section{Gifts}

The most obvious test for determining the intent of the depositor is that stated in the law of gifts. Both under the English view ${ }^{2}$ and the law of this country, the donor must intend to make a gift and must surrender control of the subject matter. ${ }^{3}$ The third requisite is that there must be an acceptance by the donee, ${ }^{4}$ which is usually presumed. Applying the gift test to the bank account transaction, courts formerly held that the donation failed because the donor had not relinquished all dominion over the account. ${ }^{5}$ This was based on the reasoning that the gift was inchoate, for the donor could defeat the gift by his act of withdrawing the funds. ${ }^{6}$

The difficulty of applying the traditional law of gifts is that it does not coincide with the depositor's intention. Since he does not desire to make a gift of the entire account, he does not surrender dominion over the funds. $\mathrm{He}$ is earnestly attempting to perfect a gift of the balance in the account as of the time of his death. He is willing to make some concession to the law of gifts, for he recognizes that if the donee acquires no rights at all in the account until the donor's death the transaction is testamentary in character, and is void because of noncompliance with the statute of wills. However, the donor is unwilling to surrender all control.

The more realistic nature of the transfer has been recognized in a number of jurisdictions. It is not a gift of the entire account but rather a donation of a partial interest in the form of the present right to withdraw added to the right of survivorship. This lias been construed as a gift of a coequal right in the donee of a present power to exercise control over the account. ${ }^{8}$ By the gift, the benefactor has created a joint interest equal to his own in the form of rights of contract or of an interest in property. The donor relinquishes exclusive dominion over the account, an act which sat-

${ }^{1}$ O'Brien v. Biegger, 233 Iowa 1179, 11 N.W.2d 412 (1943); Menger v. Otero County State Bank, 44 N.M. 82, 98 P.2d 834 (1940).

2 Pollock, Gifts of Chattels without Delivery, 6 I. Q. REv. 446 (1890).

3 Havighurst, Gifts and Bank Deposits, 14 N. C.L. Rev. 129 (1936).

4 Brown, A Treatise on the LaW of Personal Property 189 (1936).

- Clark v. Young, 246 Ala. 529, 21 So.2d 331 (1945); Clark v. Bridges, 163 Ga. 542, 136

S.E. 444 (1927); Bath Savings Institution v. Fogg, 101 Me. 188, 63 Atl. 731 (1906).

6 Ibid.

7 See notes 8-9 infra.

8 State Board of Equalization v. Cole, 122 Mont. 9, 195 P.2d 989 (1948).

9 Burns v. Nolette, 83 N.H. 489, 144 Atl. 848 (1929). 
isfies a requisite that there be a delivery of the res. ${ }^{10}$ The power to withdraw does not invalidate the gift of a joint interest. ${ }^{11}$ There is no reason why a donation made in this form should not be sustained. The transaction is exactly what the donor intended; namely, a gift of a joint interest with the right of survivorship. As one court has suggested, "There can be no doubt that the owner of personal property has the right to give it away in whole or in part; consequently, he can give a joint ownership to another." 12

Formalities required by the bank for opening an account minimize the danger of fraud or undue influence, the two facts which influenced courts to require delivery of the subject matter before a gift would be recognized. If, in fact, there is fraud, undue influence or incapacity, the transaction may be examined and if the beneficiary has participated and gained from his conduct the gift will not be recognized. ${ }^{13}$

\section{Trusts}

At least four states ${ }^{14}$ have applied the trust theory, at one time or another, to determine the interest acquired by the survivor in a joint bank account. It is to be observed that this is not a deposit made in trust for another, but rather a joint account upheld as a trust on the theory that the form of the account shows the intent to give the donee an equitable interest.

The trust theory raises some rather serious problems. One difficulty is the fact that the creation of a trust imposes the obligation of a fiduciary on the depositor. This is a situation which he neither bargained for nor desired when he opened the account in joint form. Furthermore, there is no evidence that he desires to separate the equitable from the legal ownership. While the depositor may want to postpone enjoyment of possession by the donee, he does not wish to separate the legal from the equitable interest, or place any restrictions on his own power to use the funds.

One of the most serious objections to the trust theory is the fact that had the depositor desired to create a trust of any type, he could have opened the account in trust form ${ }^{15}$ rather than in joint or survivorship form. As a practical matter the trust type of bank account antedated the joint and survivorship account. Since bankers and lawyers are familiar with this type of

10 Beach v. Holland, 172 Ore. 396, 142 P.2d 990 (1943).

11 First Nat. Bank \& Trust Co. of Fargo v. Green, 66 N.D. 160, 262 N.W. 596 (1935).

12 Industrial Trust Co. v. Scanlon, 26 R.I. 228, 58 Atl. 786 (1904).

13 See notes 146 and 203 infra.

14 Booth v. Oakland Bank of Savings, 122 Cal. 19, 54 Pac. 370 (1898) ; Bath Savings Institution v. Fogg, 101 Me. 188, 63 Atl. 731 (1906) ; Milholland v. Whalen, 89 Md. 212, 43 Atl. 43 (1899); Hoboken Bank for Savings v. Schwoon, 62 N.J. Eq. 503, 50 Atl. 490 (Ch. 1901).

15 The Tentative Trust gives the depositor unrestrained control over the account during his lifetime. See Restatement, Trusts $\$ 58$ (1948 Supp.). The depositor may also create an irrevocable trust of the entire deposit. For a discussion of the distinction between the two types of bank account trusts see, ScOTT, LAW OF TRUSTs 354 (1939). 
account, it seems reasonable to assume that the failure to open an account in trust form indicates the depositor has no intention to enter into a trust. In fairness to the courts, it should be pointed out that the trust theory has been generally rejected. ${ }^{16}$ The inference should not be drawn that it is impossible for the survivor of a joint account to hold the funds in trust for a named beneficiary. However, such a trust is created by reason of a parol understanding and not by virtue of the form of the account. ${ }^{17}$

\section{Joint Tenancy}

The common law joint tenancy has been described as creating an interest in property by which the tenants are possessed per my et per tout. ${ }^{18}$ Practically speaking, the most important incident of this form of concurrent ownership is survivorship. Since it was necessary, in order to create a common law joint tenancy, that the unity of time, title, interest and unity of possession be present, ${ }^{10}$ it was common to speak of the four unities in connection with joint tenancies.

This form of joint estate was recognized in England and was received as a part of the common law of property. However, it fell into disfavor both legislatively and judicially so that for a great many years a joint tenancy was not recognized in a number of jurisdictions. ${ }^{20}$ This is not to say that survivorship could not be created by an instrument. ${ }^{21}$ The interest was transferred to the survivor by reason of the contract and not because a common law joint tenancy was created with the right of survivorship.

The phrase "joint tenancy," when applied to joint bank accounts, means different things in different jurisdictions, depending upon the status of this particular estate in the jurisdiction involved. In those jurisdictions which maintain the common law form of joint tenancy, a joint bank account

16 The only state which follows the trust theory is Maryland. In Milholland $\mathrm{v}$. Whalen, $89 \mathrm{Md}$. 212, 43 Atl. 43 (1899) the Court of Appeals of Maryland construed a deposit made as follows, "In account with Elizabeth O'Neil. In Trust for herself and Mrs. Mary Whalen, widow, joint owners, subject to the order of either; the balance at the death of either to belong to the survivor." The Maryland court held that a trust was created by the above declaration for the benefit of Mrs. Mary Whalen, if the latter outlived the depositor. The depositor may withdraw all the funds during his hetime without accounting to the beneficiary. Kornmann v. Safe Deposit Co. of Baltimore, $180 \mathrm{Md}$. 270, 23 A.2d 692 (1942). Maryland joint accounts are made in trust form and are not discussed in this article.

17 Jarkieh v. Badagliacco, 75 Cal. App.2d 507, 170 P.2d 994 (1946); Matter of Estate of Schulnan, 189 Misc. 672, 72 N.Y.S.2d 239 (Surr. Ct., 1947).

182 Br. Comar. *182 (1791). The same interest is recognized in personal property. 2 Br. Comas. $* 399$ (1791).

192 Bd. Comar. $* 180 ; 2$ Am. Law of Property 8 (1952).

204 KeNT CoMrM. *362 (1834).

21 Equitable Loan \& Security v. Waring, 117 Ga. 599, 44 S.E. 320 (1903); Leverette v. Ainsworth, 199 Miss. 652, 23 So.2d 798 (1945); Jones v. Waldroup, 217 N.C. 178, 7 S.E.2d 366 (1940); Erickson v. Erickson, 167 Ore. 1, 115 P.2d 172 (1941); Mardis v. Steen, 293 Pa. 13, 141 Atl. 629 (1928). 
will not constitute the depositors joint tenants. ${ }^{22}$ Courts find that the unity of possession and the unity of time are lacking. With respect to the latter, some courts have stated that opening a joint account is a mere splitting of interests, so that the depositor and the donee do not acquire their interest at the same time..$^{23}$ This view does not seem sound. The transaction is equivalent to a conveyance and a reconveyance, a device well known to property lawyers. ${ }^{24}$ The depositor has exchanged money for a joint interest in a chose in action. He and his co-depositor claim their rights as of the same time. If the account is changed from individual form to joint form a novation is effected, and the bank substitutes an obligation to joint obligees for its debt to the depositor. This would appear to satisfy the unity of time.

A more serious objection to the common law form of joint tenancy is that there is no real unity of interest. ${ }^{25}$ The donee ostensibly holds an interest equal to that of the depositor but the former actually has only the interest which the donor intends to give to him. There is no real unity in the usual joint account, since one party reserves the right to use all of the funds without accounting to the other. This is borne out by the fact that during the depositors' joint lives the depositor may show that he did not intend to make a gift of the account, and that the account was in joint form for his own convenience. ${ }^{26}$ The absence of a unity of interest supports the view of the courts that the rights of the survivor to the account cannot be upheld on the ground that a common law joint tenancy has been created.

As mentioned in a preceding paragraph, ${ }^{27}$ although joint tenancy was viewed with disfavor in this country for a long period of time, the right to provide for survivorship has been accepted. This has been accomplished in some jurisdictions by legislation decreeing that whenever the parties provide for survivorship a joint tenancy will be recognized and the rights of the survivorship will be enforced. ${ }^{28}$ This type of statute affirmatively recognizes joint tenancies and the right of survivorship ${ }^{29}$ and applies to personal as

22 Staples v. Berry, 110 Me. 32, 85 Atl. 303 (1912); In re Lower's Estate, 48 S.D. 173, 203 N.W. 312 (1925) (modified by statute, S.D. Laws 1951, c. 255 \& 1).

23 Appeal of Garland, 126 Me. 84, 136 Atl. 459 (1927); Rice v. Bennington County Sav. Bank, 93 Vt. 493, 108 Atl. 708 (1920).

24 On the theory that one may create a joint tenancy in property held by the grantor by a conveyance through a trustee, it has been urged that a grantee should be able to convey a joint tenancy directly to himself and another. Switzer v. Pratt, 237 Iowa 788, 23 N.W.2d 837 (1946).

25 Staples v. Berry, 110 Me. 32, 85 Atl. 303 (1912).

26 See cases cited at note 114 infra.

27 See text at note 20 supra.

28 Cax. Civ. Code $\$ 683$; Colo. Stat. Ann. c. 92, §17 (1938); Mont. Rev. Codes Ann. § 67-310 (1947); Nev. CoMrp. Laws §3710 (Supp. 1931); N.Y. REAL. Prop. Law § 66; N.H. Rev. Laws c. 178, p. 382 (1951); N.M. STAT. ANn. \$ 75-111 (1941); OKLa. StaT., tit. 60, § 74 (Cuin. Supp. 1947); S.D. LAws, 1951 c. 255, \& 1; VA. Code Avw. § 55-21 (1949); W.VA. Code ANN. \$ 3540 (1939).

20 Observe that the statutes cited infra note 32 authorize joint tenancies in a negative manner. 
well as real property. ${ }^{30}$ Since the legislature has favored survivorship, it is not difficult for the courts to find that the depositor intends to create a joint tenancy when he opens an account in joint survivorship form. ${ }^{31}$

A second type of statute regulating joint tenancy in general provides that a conveyance to two or more persons creates a tenancy in common unless the parties indicate that they intend that a joint tenancy should be created..$^{32}$ This type of enactinent establishes a presumption against joint tenancy, but does not prohibit it. ${ }^{33}$ It has been easy for courts to view the legislature's consent to the creation of joint tenancies as an invitation for the recognition of this type of concurrent estate any time that the parties provide for survivorship. While it has been argued that the statute eliminates the necessity of the four unities, ${ }^{34}$ the better rule would seem to be that this type of statute does not change the formal requisites essential for the creation of the estate, but only adds the requirement that the grantor's intent for survivorship be clearly expressed. ${ }^{35}$ Under this type of statute joint depositors should not be considered joint tenants.

A third legislative technique is to abolish jus accrescendi as an incident of joint tenancy. ${ }^{36}$ In spite of such enactments courts have stated that when the grantor or conveyor indicates that he desires survivorship his intent will

30 The general rule appears to be that if a joint tenancy is recognized, it will apply to personalty. If not permitted in realty, it will not exist in personalty. Lober v. Dorgan, 215 Mich. 62, 183 N.W. 942 (1921) ; Peterson v. Lake City Bank \& Trust Co., 181 Minn. 128, 231 N.W. 794 (1930) ; Nichols v. Denny, 37 Miss. 59 (1859); Pierce v. Baker, 58 N.H. 531 (1879); In re Kimberly's Estate, 150 N.Y. 90, 44 N.E. 945 (1896); Reel v. Hansboro State Bank, 52 N.D. 182, 201 N.W. 861 (1924). Contra: Stout v. Van Zante, 109 Ore. 430, 220 Pac. 414 (1923); Noe's Adm'rs. v. Miller's Ex'rs., 31 N.J. Eq. 234 (Ch. 1879); Town of Corinth v. Emery, 63 Vt. 505, 22 Atl. 618 (1891).

31 Most of the states which expressly provide for joint tenancies in property generally, have statutes authorizing the creation of a joint tenancy in joint bank accounts. See notes 67-75 infra.

32 ARr. STAT. \$ 50-411 (1947); DEr. REv. CODE $\$ 3735$ (1935); FrA. STAT. § 689.15 (1949); IDAHO CODE § 26-1014 (1947) ; BURNS' IND. ANN. STAT. § 51-104 (1949); IOWA CODE § 557.15 (1946) ; Kan. Laws, c. 181 \& (1939); MrcH. CoMrp. Laws \$ 554.44 (1948); MISs. Code $\S 834$ (1942) ; Mo. Rev. Stat. AnN. \$3504 (West 1939); N.J. Rev. Stat. 46: 3-17 (1937); UtaH Code ANN. § 7-1-5 (1933); VT. REv. STAT. \$ 2632 (1947).

33 Crabtree v. Garcia, 43 So.2d 466 (Fla. 1949); Hibbard v. Hibbard, 118 Ind. App. 292, 73 N.E.2d 181 (1947) ; In re Estate of Fast, 169 Kan, 238, 218 P.2d 184 (1950).

34 The Supreme Court of Oklahoma stated that simce the term "joint tenancy" had a well defined ineaning at common law, and inasmuch as the legislature did not define the term in the statute recognizing joint tenancies, the phrase "joint tenancy" was presumed to have been used in its technical common law sense. Draughon v. Wright, 200 Okla. 198, 191 P.2d 921 (1948). Contra: Jones v. Jones, 185 Tenn. 586, 206 S.W.2d 301 (1947).

35 The common law rule was that a joint tenancy would be presumed from a conveyance to two persons. 2 TLFFANY, Law of Real Property 201 (3rd 1939).

36 ARIz. CODE ANN. \$ 39-110 (1939); N.C. Gen. Stat. \$ 41-2 (1950); Ore. Comp. Laws ANn. § 70-205 (1940); PA. Stat. ANN. tit. 20, § 121 (1941); S.C. Code § 8911 (1942); TenN. Code Ann. $\$ 7604$ (Williams (1934); Tex. Rev. Crv. Stat. Ann., art. 2580 (Vernon's 1936); WASH. REV. STAT. § 1344 (1932). 
prevail ${ }^{37}$ Reasoning that the statute abolishing jus accrescendi did not abolish the contractual right to provide for survivorship, the courts have enforced the rights of the survivor arising by reason of the instrument creating the joint interest..$^{38}$ It is not always clear whether joint tenancies have been abolished, with the result that the only rights to which the survivor is entitled arise by reason of the instrument, or whether joint tenancy still exists without survivorship. ${ }^{39}$ If the latter is true it would appear to be necessary to have the four unities and the expressed provision creating survivorship, in order to have the joint tenancy. Obviously joint bank accounts would not satisfy the former although conceivably they would satisfy the latter qualification.

In some jurisdictions joint tenancies as such have been abolished. ${ }^{40}$ Nevertheless, it is possible to create a tenancy in common with the right of survivorship, ${ }^{41}$ on the theory that the parties are tenants in common for life, with a remainder in fee to the survivor. ${ }^{42}$ Technically speaking the joint bank accounts would not satisfy the requisites necessary to fall withm these classifications since the depositor does not intend to create a tenancy in common, which would give the donee an immediate and equal share.

In the absence of either a special statute providing that the parties to a joint account hold as joint tenants or an enactment providing for the creation of joint tenancy in personal property by contract, a joint bank account should not be considered as having created a joint tenancy. The usual property concepts do not apply. Some earlier cases following the joint tenancy theory have been overruled. As has been pointed out by the Supreme Judicial Court of Massachusetts, the very nature of a joint account which gives the depositor the right to draw a part or all of the funds without accounting to the donee repudiates the idea that a joint tenancy has been created with the donee holding an undivided half-interest with the right of survivorship..$^{43}$ While joint depositors may have joint interests, they should not be classed as joint tenants. The interest is only analogous to a joint tenancy.

37 Erickson v. Erickson, 167 Ore. 1, 115 P.2d 142 (1941).

38 Arnolds v. Jacks' Executors, 24 Pa. 57 (1854); Tacoma Sav. \& Loan Ass'n. v. Nadham, 14 Wash. 2d 576, 128 P.2d 982 (1942).

39 Chandler v. Kountze, 130 S.W.2d 327 (Tex. Civ. App. 1939).

40 Allen v. Almy, 87 Conn. 517, 89 Atl. 205 (1913); Equitable Loan \& Security Co. v. Waring, 117 Ga. 599, 44 S.E. 320 (1903) ; Miles v. Fisher, 10 Ohio 1 (1840).

41 Whittlesey v. Fuller, 11 Conn. 337 (1836); Equitable Loan \& Security Co. v. Waring, stlpra note 40; Berberick v. Courtade, 137 Ohio St. 297, 28 N.E.2d 636 (1940).

42 Blodgett v. Union \& New Haven Trust Co., 111 Conn. 165, 149 Atl. 790 (1930).

43 Marble v. Jackson, 245 Mass. 504, 139 N.E. 442 (1923) impliedly overruling Attorney General v. Clark, 222 Mass. 291, 110 N.E. 299 (1915). 


\section{Contracts}

The most recent theory ${ }^{44}$ in those states that do not have special statutes regulating the right of parties to joint accounts is the contract theory, which has been stated as follows:

Upon deposit of an account the bank is constituted as a debtor, and when the depositor orders the bank to pay himself and another upon the order of either party, secures the signature of the second party, evidencing assent to the arrangement and notifies her of the completed transaction, he has created in the second party by contract a joint interest in the account equal to his own. ${ }^{45}$

Although the transaction is sometimes declared to be testamentary, ${ }^{40}$ usually it is upheld on the theory that a present contractual right has been created, notwithstanding that the full enjoyment on the part of the donee is postponed until the death of the person furnishing the funds. ${ }^{47}$ But as originally stated, the contract theory was defective. There is nothing in the contract that transfers the property from the depositor to the donee. The agreement merely instructs the bank to make payment without purporting to determine the rights between the payees. Unless the transfer to the codepositor is by some technique recognized in law, the property remains the depositor's and upon his death belongs to his estate.

The more realistic approach has been a recognition that the transaction is, in reality, a gift and that the contract is the substitute for delivery. ${ }^{48}$ When the parties execute an instrument which recites that the bank is the debtor of the joint obligees, and that either of the creditors may withdraw any or all of the funds, exclusive control is relinquished by the depositor. The question then is whether or not the depositor has intended a gift or whether the account has been opened only for his own convemence. It is submitted that the so-called contract theory is, in reality, either a gift of a partial interest or a contractual creation of a right of survivorship in a statutory joint tenancy, in which the joint tenant waives his right to require the depositor to account for the funds withdrawn by him.

THE STATUTES GOVERNING THE PAYMENT OF JOINT ACCOUNTS

\section{The Bank Protection Type of Statute}

Every state in the umion, except Kentucky, has enacted legislation regu-

44 Malone v. Sullivan, 136 Kan. 193, 14 P.2d 647 (1932); Bishop v. Bishop's Executors, 293 Ky. 652, 170 S.W.2d 1 (1943); Holt v. Bayles, 85 Utah 364, 39 P.2d 715 (1935); Deal's Adm'r. v. Merchants \& Mechanics Bank, 120 Va. 297, 91 S.E. 135 (1917).

45 Cleveland Trust Co. v. Scobie, 114 Ohio St. 241, 151 N.E. 373 (1926).

46 Stevenson v. Earl, 65 N.J. Eq. 721, 55 Atl. 1091 (Ct. Err. \& App. 1903) ; Olive v. Olive, 231 S.W.2d 480 (Tex. Civ. App. 1950).

47 Chippendale v. North Adams Savings Bank, 222 Mass. 499, 111 N.E. 371 (1916); Sagc v. Flueck, 132 Ohio St. 377, 7 N.E.2d 802 (1937).

48 Castle v. Wightman, 303 Mass. 74, 20 N.E.2d 436 (1939). 
lating the payment of accounts opened in the name of two or more individuals. While these enactments were originally adopted for the protection of the bank so that it could make payment to the survivor of a joint account without being liable to the estate of the depositor, ${ }^{49}$ their function has now been extended, in a number of states, to include the distribution of the depositor's property.

In general, there are three types of statutes. The most popular type, which has been adopted in thirty-four jurisdictions, ${ }^{50}$ in substance provides that a deposit made in the name of two or more persons, payable to either or the survivor, may be paid to either of the persons named whether the co-depositor be living or not. The receipt or acquittance of the person so paid is a valid release and discharge to the bank for any such payment. The statute has been construed in most jurisdictions to be enacted for the protection of the bank and not for the purpose of fixing rules of property. ${ }^{51}$ Even in the jurisdictions that have not expressly so interpreted the statute, the absence of any mention of the statute in controversies involving joint

\footnotetext{
49 Banks had been defendants in a number of suits brought in New York by the depositor's estate to recover the amount paid by the bank to the survivor following the depositor's death, or by the survivor to force the bank to make payment notwithstanding that the depositor's estate claims the account. Mulcahey v. The Emigrant Industrial Bank, 89 N.Y. 435 (1882); Whitlock v. The Bowery Savings Bank, 36 Hun. 460 (Sup. Ct. Gen. Term 1885) ; McElroy v. Albany Savings Bank, 8 App. Div. 46, 40 N.Y. Supp. 422 (3d Dep't, 1896); Grafing v. Irving Sav. Inst., 37 Misc. 20, 74 N.Y. Supp. 741 (Sup. Ct. 1902); Kelly v. Home Sav. Bank of Albany, 103 App. Div. 141, 92 N.Y. Supp 578 (3d Dep't 1905).

E0 ARIz. Code ANn. § 51-516 (Cum. Supp. 1952); Conn. Gen. Stat. c. 278, § 5831 (1949); Det. Rev. Code $\$ 2270$ (1935); D.C. Code ANr. § 26-204 (1940); FLA. Stat. ANr. § 653.16 (Cum. Supp. 1949); Ga. Code ANv. § 13-2039 (1933); Idaro Code § 26-1014 (1947); IND. ANN. Stat. § 51-104 (Burns Supp. 1951) ; Iowa CodE § 528.64 (1950); KAN. GEN. Stat. § 9-1205 (Supp. 1949) ; LA. Rev. Stat. § 6-32 (1950); MD. Code, art. 11, § 101 (1939); Mass. Acts 1953, c. 334, § 1; Mrnv. Stat. §48.30 (1949); Mrss. Code Anv. §5205 (1942); Mont. Rev. Code ANN. § 5-528 (1947); Neb. REv. StaT. § 8-167 (1943); N.H. Rev. Laws c. 309, § 20 (1942); N.M. Stat. ANN. § 50-1003 (1941) ; N.C. Gen. StaT. § 53-146 (1943) ; N.D. REv. Code § 6-0366 (1943); O\#то CoDE ANN. §710-120 (1948); OrLA. STat. tit. 6, §118 (1941); as amended by Session Laws 1945, c. 6a, $\S 1$; Ore. Comrp. Laws ANN. $\S 40-1003$ (1940); Pa. Stat. AnN. tit. 7, § 819-904 (1941); R.I. GEN. Laws c. 135, §3 (1938); S.C. Code $\$ 7851$ (1942); S.D. Lawis 1951, c. 13, § 1; Tenn. Code ANn. \$ 5935.1 (Supp. 1949); Tex. Rev. Crv. Stat. Ann. art. $342-701$ (1948); UTAH COdE ANN. § 7-3-45 (1953); VA. CODE § 6-55 (1950); Wrs. Stats. 1949, § 221.44; Wyo. Comp. Stat. ANv. \& 35-148 (1945).

81 Gibson v. Industrial Bank of Washington, 36 A.2d 62 (D.C. Mun. Ct. App. 1944); Cerny v. Cerny, 152 Fla. 333, 11 So.2d 777 (1943); Clark v. Bridges, 163 Ga. 542, 136 S.E. 444 (1927) ; Malone v. Sullivan, $136 \mathrm{Kan} .193,14$ P.2d 647 (1932) ; Northcott v. Livingood, 10 So.2d 401 (La. App. 1942) ; Mathias v. Fowler, 124 Md. 655, 93 A.2d 298 (1915) ; New Hampshire Sav. Bank v. McMullen, 88 N.H. 123, 185 Atl. 158 (1936); Nichols v. Metropolitan Life Ins. Co., 137 Ohio St. 542, 31 N.E.2d 224 (1941) ; Lay v. Proctor, 147 Ore. 545, 34 P.2d 331 (1934); Peoples Sav. Bank in Providence v. Rynn, 57 R.I. 411, 190 Atl. 440 (1937) ; Pruett v. First Nat. Bank of Temple, 175 S.W.2d 658 (Tex. Civ. App. 1943); Holt v. Bayles, 85 Utah 364, 39 P.2d 715 (1934).
} 
accounts indicates that the courts do not consider it to relate to the transfer of property. ${ }^{52}$

Notwithstanding the majority rule, cases adjudged in Iowa, Minnesota, Mississippi, Nebraska and Wisconsin assert that the law was enacted by the legislature not only to protect the bank but also as an aid to determine the rights of the survivor. The cases do not all construe the statute in the same light, although the effect in all instances is the same. For example, the Iowa courts have noted that the law, which provides for the payment of the balance in the account, may be considered as an incentive for the establishment of the account. ${ }^{53}$ The Supreme Court of Wisconsin has taken a similar position, noting that the statute recognizes the right of survivorship where the deposit is in the name of two persons, payable to either or the survivor. ${ }^{54}$

The Supreme Courts of Minnesota, Mississippi and Nebraska have taken a more positive stand on the construction of the statute. The Minnesota Supreme Court has stated that from the fact that the statute authorizes the payment of the balance to the survivor, "a presumption arises that such residue is the absolute property of the survivor, and calls upon those who claim otherwise the burden of proving that such was not the intention of the donor." 55

Adopting a similar, practical analysis of the situation, the Mississippi Supreme Court has stated that the provision for paying to the survivor sanctions the practice of accounts being carried in such a manner, and "such authority conferred upon the banks is evidently founded on the presumption that the parties intended that they should be paid to the survivor."150 The same result is reached by the Nebraska court through an analysis that since the depositor knows of the statute, and inasmuch as he knows the bank will follow its provisions, the legislature must also have had that result in mind when it adopted the statute. ${ }^{5 T}$ The Nebraska legislature has acquiesced in the construction placed on the statute..$^{\text {ss }}$

Even in those jurisdictions recognizing that the banking statute may influence the court's decision in determining the rights of the survivor to a joint account following the death of the depositor, the transfer of the funds in the account from the depositor to the donee inust be made in accordance

52 Cases involving the payment of the funds in joint bank accounts without reference to the survivor, have been decided in Arizona, Connecticut, Indiana, Montana, New Mexico, North Carolina, North Dakota, Oklahoma, Pennsylvania, South Carohna, South Dakota, Tennessee and Virginia.

53 O’Brien v. Bieggar, 233 Iowa 1179, 11 N.W.2d 412 (1943).

54 Estate of Staver, 218 Wis. 114, 260 N.W. 655 (1935).

55 Dyste v. Farmers and Mechanics Bank, 179 Minn. 430, 229 N.W. 865 (1930).

50 In re Lewis' Estate, 194 Miss. 480, 13 So.2d 20 (1943).

57 Estate of Johnson, 116 Neb. 686, 218 N.W. 739 (1928).

58 McConnell v. McCook Nat. Bank of McCook, 142 Neb. 451, 6 N.W.2d 599 (1942). 
with some recognized rule of law. It is obvious, in the thirty-four jurisdictions which have the bank protection type legislation, the rights of all parties, including the creditors, widow and others, must be determined under the common law. We therefore have a body of law which has evolved around joint bank accounts, and which will be treated elsewhere in this paper. 50

\section{The Joint Tenancy Type of Statute}

The first legislation which authorized the payment to the survivor of the funds deposited in the joint account was enacted in New York in 1907.60 Following the adoption of this legislation there arose a number of controversies in New York concerning the question as to whether the survivor was entitled to the account, or whether the account was opened merely for the convenience of the depositor, in which case the survivor would not acquire any interest surviving the death of the depositor. ${ }^{61}$ The New York cases have gone so far as to hold that a presumption existed to the effect that the account was for the convemence of the depositor ${ }^{62}$ unless the two parties to the account were husband and wife..$^{63}$

In $1909^{64}$ the Savings Bank Act was amended in the state of New York to provide that when an account was opened in any savings bank in the name of the depositor and another, and in form to be paid to either or the survivor, the account should become the property of such persons as joint tenants. Following the adoption of this legislation the New York courts recognized that the legislature had created a statutory joint tenancy, and that providing for the right of survivorship was an acceptance of such tenancy. However, it was held that the estate of the depositor could show that the account was opened only for the convenience of the depositor and that it was not the latter's intention to transfer the property interests to the co-depositor, notwithstanding the statute and the fact that the depositor had intentionally opened the account in this manner. ${ }^{65}$ The legislature subsequently amended the savings bank law so as to provide that the opening

60 See infra at note 95 .

60 N.Y. Laws 1907 , c. 247.

61 Moore v. Fingar, 131 App. Div. 399, 115 N.Y. Supp. 1035 (1st Dep't 1909) ; Hemmerick v. Union Dime Savings Inst., 205 N.Y. 366, 98 N.E. 499 (1912) ; Bonnette v. Molloy, 153 App. Div. 73, 138 N.Y. Supp. 67 (1st Dep't 1912), rev'd on other grounds, 209 N.Y. 167, 102 N.E. 559 (1913).

62 In re Bolin, 136 N.Y. 177, 32 N.E. 626 (1892).

63 West v. McCullough, 123 App. Div. 846, 108 N.Y.Supp. 493 (2d Dep't 1908), aff'd, 194 N.Y. 518,87 N.E. 1130 (1909).

64 N.Y. Laws 1909, c. $10 \S 144$.

65 Clary v. Fitzgerald, 155 App. Div. 659, 140 N.Y. Supp. 536 (4th Dep't 1913), aff'd, 213 N.Y. 696, 107 N.E. 1075 (1915). 
of an account in joint and survivorship form created a conclusive presumption of joint tenancy, if there were no fraud or undue influence. ${ }^{66}$

At the present time nine states have on their statute books laws stating that a deposit made by any person in the name of such depositor and another person, and in form to be paid to either or the survivor of them, shall become the property of such persons as joint tenants. In New York a deposit made in a savings bank in such form creates a conclusive presumption, while if made in any other type of banking institution it only creates a rebuttable presumption of joint tenancy ${ }^{67}$ Nevada $^{68}$ and Washington ${ }^{60}$ follow the New York savings bank statute, while Arkansas, ${ }^{70}$ California, ${ }^{71}$ Colorado, ${ }^{72}$ Michigan, $^{73}$ Missouri ${ }^{74}$ and West Virginia ${ }^{75}$ follow the New York commercial bank statute. In all nine states, a joint tenancy is created by the opening of the account in statutory form. The rights of the parties interested in the account are determined in accordance with the law of joint tenancy as adopted in that particular jurisdiction. These rights are elsewhere discussed in this article. ${ }^{76}$

\section{Special Statutes Governing Joint Bank Accounts}

In five jurisdictions special statutes have been enacted to determine the rights of the survivor to a joint account. Most of these enactments were adopted for the express purpose of overruling a court decision which had denied survivorship in a particular case. This is demonstrated forcibly by the Alabama statute adopted in $1945^{77}$ following the adjudication of Clark v. Young ${ }^{78}$ in 1944. Although recognizing in the Clark case that the depositor had intended that the survivor should receive the amount deposited on the former's death, the court nevertheless lield the gift to be ineffective because of the possession and control retained by the depositor. The court furthermore stated that the writing involved in the case was testamentary in character and invalid for failure to observe the necessary requisites for executing wills. A dissent noted that the gift could be upheld on the theory of an executed contract. ${ }^{79}$

66 N.Y. BANKING LAW $\$ 239$.

67 N.Y. BANKING LAW § 134 (commercial banks); N.Y. Banknng LAw §171 (3) (private banks).

68 NEv. CoMp. LAws $\$ 743$ (1929), as amended, Stats. 1931, c. 131 \$ 1.

69 WASH. REV. CODE $\$ 30.20 .010$ (1952).

70 ARK. StAT. § 67-521 (1947).

71 CAL. BANK. Code c. 7 \$ 852 (1949).

72 Colo. Stat. Ann. c. 18, $\$ 45$ (1935).

73 MTCH. CoMrp. Laws $\$ 487.703$ (1948).

74 Mo. Rev. Stat. Ann. § 7996 (West 1939).

75 W. VA. CODE $§ 3205$ (1943).

78 See cases cited note 153 infra.

77 ATA. CoDE tit. 5, § 128(2a) (Supp. 1949).

ז8 246 Ala. 529, 21 So.2d 331 (1944).

79 Id. $246 \mathrm{Ala}$. at 538, 21 So.2d at 338. 
The Alabama joint account statute was subsequently amended ${ }^{80}$ to provide that where a deposit is made in the name of two persons, payable to either or the survivor, the deposit shall become the property of the survivor. The statute further stated that payment is to be made irrespective of whether or not the funds were the property of only one of the said persons, or whether there was an intent on the part of such person to vest the other with the present interest, or whether or not only one of the said persons during their lives had the right to withdraw such deposits, and also irrespective of whether or not there was a delivery of his bank book, account book, savings book or certificate of deposit by the person making a deposit to the other. The enactment added that the right of the person making the deposit to withdraw during his lifetime shall not defeat the rights of the person surviving such depositor.

A similar statute was enacted by the Maine legislature following the denial of the right of the survivor to the proceeds of a joint account. In Appeal of Garland ${ }^{81}$ the Supreme Judicial Court of Maine found that the surviving wife was not entitled to the balance of a joint and survivorship account. The court considered the question as to whether or not there was a gift and found that there was not one because the depositor retained full control over the account during his lifetime. The tribunal rejected the argument that a joint tenancy had been created, stating that the four unities necessary for the creation of joint tenancy were not present. They refused to apply the contract theory, holding that the contract was void because of non-compliance with the statute of wills. As a result of this case the Maine legislature ${ }^{82}$ amended its joint bank account statute to provide that an account, payable to either or the survivor, and opened in the name of two or more persons who are husband and wife or parent and child, and not exceeding an aggregate amount of $\$ 3,000$, upon the death of either of such persons shall become the sole and absolute property of the survivor. This is subject to the proviso that there has been no fraud or undue influence. The act states that the balance becones the property of the survivor even though the intention of all or any one of the parties be testamentary, and even though a technical joint tenancy is not in law or fact created. It should be observed that the Maine statute differs from the Alabama law ${ }^{83}$ in that the former applies only to specified relatives and to balances not exceeding $\$ 3,000$, exclusive of dividends and interest. For accounts in the names of parties not related as stated in the statute, or for suns exceeding $\$ 3,000$, it

\footnotetext{
80 Supra note 77.

81126 Me. 84, 136 Atl. 459 (1927).

82 ME. REv. STAT. c. 55, $\$ 36$ (1944).

83 Supra note 77.
} 
would appear that the common law rules regulating the payment of joint accounts would apply. ${ }^{84}$

Vermont is another state in which the legislature has overruled a holding by the court that a survivor to a joint account is not entitled to a balance remaining at the depositor's death, because there has not been a compliance with any of the recognized means for transferring property. In Rice v. Bennington County Savings Bank ${ }^{85}$ the Supreme Court of Vermont held that the depositor had neither made a gift of the balance in the account nor had he created a joint tenancy. The evidence indicates that the depositor had intended to provide for survivorship. Three years after the Rice litigation the legislature amended the bank account statute ${ }^{86}$ by adding to it the provision that the recital of the words, "payable to either or the survivor" in the order creating such an account, sigued by the person or persons who furnished the funds for such deposit, shall be conclusive evidence as between the payees and their legal representative of the creation of an absolute joint account. The door was left open for introduction of evidence of fraud, undue influence or incapacity. In subsequent litigation the court recognized that the amendment of the statute had been for the purpose of superseding the Rice case by allowing "donative intention to prevail without the technical formality of the delivery of a deposit book." "87

A reading of the New Jersey law pertaining to joint accounts would lead one to believe that that part of the banking act which relates to joint accounts creates a rule of property much in the same way as the Alabama legislation. The New Jersey statute reads as follows:

When a deposit has been or shall be made with a banking institution in the name of two persons, payable to either, or payable to either or to the survivor, any moneys to the credit of the account may be paid to either of said persons during the lives of both and, in case of the death of either of said persons, the moneys to the credit of the depositor shall, unless otherwise provided in the deposit contract, be paid to the survivor, and the legal representative of the one dying shall have no right thereto notwithstanding that such moneys or any part thereof may have been the property of the one dying. Nothing in this section shall impair the rights, if any, of creditors of either depositor. 88

However, the New Jersey courts have in a number of instances construed the above statute and have held that neither the form nor the content of a joint account is conclusive of the issue of title and ownership, and that

84 The result would be governed by Appeal of Garland, $126 \mathrm{Me} .84,136$ Atl. 459 (1927); and Rose v. Osborne, $133 \mathrm{Me} .497,180$ Atl. 315 (1935).

8593 Vt. 493, 108 Atl. 708 (1920).

86 VT. REv. STAT. $\$ 8780$ (1947).

8T Patch v. Squires, 105 Vt. 405 at 409,165 Atl. 919 at 920 (1933).

88 N.J. STAT. AnN. $\$ 17.9$ A-218 (Supp. 1952). 
the statute "lays down a rule of evidence rather than the substantive law." The interest of the survivor, states the court, ${ }^{90}$ arises from the fact that the depositor has made a gift inter vivos of an interest in the account. The statute merely gives rise to a rebuttable presumption of a gift. It would appear therefore that the rights of the parties in any controversy in New Jersey would be determined under the common law of joint bank accounts.

The Illinois enactment is different from any of the others in this category. The section pertaining to joint bank accounts is found in the chapter of the Revised Statutes, entitled: "Joint Rights and Obligations." The statute provides that except as to executors and trustees, and except where wills and other instruments in writing express an intention to create a joint tenancy in personal property, with the right of survivorship, the right or intent of survivorship as between joint tenants or owners of personal property are abolished. This is followed by a proviso that when a deposit in any bank or trust company has been made in the names of two or more persons, payable to them when the account is opened or thereafter, such deposit or any part thereof or any interest or dividend thereon may be paid to any one of said persons whether the other or others be living or not when the agreement permitting such payment is signed by said persons at the time the account is opened or thereafter. The statute further provides that the receipt or acquittance of the person so paid shall be a valid and sufficient discharge from all parties so paid.

The statute appears to be somewhat ambiguous. However, it has been construed by the Supreme Court of Illinois ${ }^{92}$ to provide that the right of survivorship in personal property jointly owned is preserved where an instrument in writing expresses an intention to create a joint tenancy with the right of survivorship. While there are decisions ${ }^{93}$ stating that Illinois follows the contract theory, it would appear that the contract creates a statutory joint tenancy. ${ }^{94}$ The rights of the parties, once a statutory account has been opened, should be decided in accordance with the general principles governing joint tenancy bank accounts, ${ }^{95}$ but in view of the wording of the statutes, the Illinois decisions are treated specially.

These special statutes are significant, not because of the language the legislature employs in the law, but rather because they represent a recog-

89 In re Perrone's Estate, 5 N.J. 514, 76 A.2d 518 (1950).

90 Stiles v. Newschwander, 140 N.J. Eq. 591, 54 A.2d 767 (Ct. Err. \& App. 1947).

91 ILL. REv. STaTs. c. $76 \$ 2$ (1951).

02 III. Trust \& Sav. Bank v. Van Vlack, 310 III. 185, 141 N.E. 546 (1923) ; Estate of Halaska, 307 Ill. App. 183, 30 N.E.2d 117 (1940).

93 Reder v. Reder, 312 III. 209, 143 N.E. 418 (1924) ; Estate of McIlrath, 276 Ill. App. 409 (1934) ; Cuilini v. Northern Trust Co., 335 Ill. App. 86, 80 N.E.2d 275 (1948).

94 Estate of Wilson, 404 IIl. 207, 88 N.E.2d 662 (1949); Welsh v. James, 408 Ill. 18, 95 N.E.2d 872 (1950).

95 See note 153 infra. 
nition by the lawmakers that the joint bank account is a new but acceptable technique for transferring property, and that it should be recognized as such.

\section{THE COMMON LAW OF JOINT BANK ACCOUNTS}

\section{In General}

From the fact that courts apply various theories to test the validity of the jomt bank account transaction it might appear that the joint bank account is looked upon with judicial disfavor. While it is true that in many instances courts have voided the transfer front the depositor to the survivor on the ground that the donor had not complied with any of the recognized techniques, usually the judiciary has attempted to effectuate the depositor's intention to make a donation of his property in the creation of a joint account. The fact that there is conflict in the cases is itself witness to the attempt of the judges to make the joint account situation fit into an accepted mold for transferring property, when actually the joint account is something different from any other concept.

A study of the joint bank account at this late date may begin with the postulate that in the great majority of jurisdictions a depositor may open a joint bank account, retain control over the proceeds during his life and provide for the transfer of the balance remaining in the account at his death. ${ }^{96}$ As has been pointed out in this discussion, in some jurisdictions the survivor may take because he is considered to be a joint tenant of the bank account. ${ }^{97}$ In other states he may be held to be the beneficiary of a contract entered into by the bank and the depositor for the survivor's benefit, ${ }^{98}$ and

${ }^{96}$ Although the theory on which the survivor was held entitled to the deposit differed from state to state, the right of the survivor to the balance was upheld in the following cases: Driscoll v. Norwich Sav. Soc., 93A.2d 925 (Conn. 1952); Quigley v. Quigley, 85 F.2d 300 (D.C. Cir. 1936); Crawford v. McGraw, 61 So.2d 484 (Fla. 1952); Hibbard v. Hibbard, 118 Ind. App. 292, 73 N.E.2d 181 (1947) ; O'Brien v. Bieggar, 233 Iowa 1179, 11 N.W.2d 412 (1943); Malone v. Sullivan, 136 Kan. 193, 14 P.2d 647 (1932); Armstrong's Ex'r. v. Morris Plan Industrial Bank, 282 Ky. 192, 138 S.W.2d 359 (1940); Armstrong v. O'Brien, 329 Mass. 572, 109 N.E.2d 647 (1952); McLeod v. Hennepin County Sav. Bank, 145 Minn. 299, 176 N.W. 987 (1920) ; In re Lewis' Estate, 194 Miss. 480, 13 So.2d 20 (1943) ; In re Sullivan's Estate, 112 Mont. 519, 118 P.2d 383 (1941) ; Scriven v. Scriven, 153 Neb. 655, 45 N.W.2d 760 (1951); Blaisdell v. Young, 90 N.H. 185, 6 A.2d 441 (1939); Lester v. Guenthen, 134 N.J.Eq. 53, 33 A.2d 815 (Ct. Err. \& App. 1943); Menger v. Otero Bank, 44 N.M. 82, 98 P.2d 834 (1940); First Nat. Bank \& Trust Co. v. Green, 66 N.D. 160, 262 N.W 596 (1935); Sage v. Flueck, 132 Ohio St. 377, 7 N.E2d 802 (1937); Green v. Comer, 193 Okla. 133, 141 P.2d 258 (1943); Beach v. Holland, 172 Ore. 396, 142 P.2d 990 (1943); Teacher v. Kijurina, 365 Pa. 480, 76 A.2d 197 (1950); Sullivan v. Dolan, 69 R.I. 492, 36 A.2d 98 (1944); Sloan v. Jones, 192 Tenn. 400, 241 S.W.2d 506 (1951); First Security Bank of Utah v. Burgi, 251 P.2d 297 (Utah 1952); Deal's Adm'r v. Merchants \& Mechanics Bank, 120 Va. 297, 91 S.E. 135 (1917); Schwanke v. Garlt, 219 Wis. 367, 263 N.W. 176 (1935).

${ }^{97}$ See text at note 18 supra.

${ }^{98}$ See text at note 44 supra. 
in still other states he may be considered as the donee of the funds remaining in the account. ${ }^{99}$ Whatever the name given to the transaction, it is, in effect, a gratuitous transfer and more and more the courts are recognizing it as such.$^{100}$ Realizing that this particular type of chose in action requires a different treatment from that accorded a chattel or a fixed obligation, courts hold that the survivor takes as a result of a gift.

The theory used to describe the transaction, whether it be denominated joint tenancy, contract or gift, is meaningful only for the purpose of defining the method of effectuating the donation. If the transfer is treated as a gift then the questions of intention, delivery and acceptance become important. If the joint account is discussed in terms of a joint tenancy, the question of the compliance with the statutory method for creating joint tenancies is material. If the joint account is explained in the terms of a contract, the formalities become inportant and the question as to whether or not the parties have signed the signature cards may become of paramount importance. But, because the transaction is gratuitous the problems relating to joint accounts are common to all jurisdictions except those that provide for special statutory joint accounts.

The rights of creditors, the surviving spouse, guardians and of the parties themselves, during their joint lives, may be discussed on common grounds. The question to be determined is whether the transfer has been completed so as to bar the rights of all the claimants except the survivor. In those states having the bank protection type statute the rights of all parties must be determined under common law principles. It is to the law in these states that this section is devoted. The jurisdictions having joint tenancy statutes or special statutes will be discussed in separate sections.

\section{Formal Requisites}

A distinction should be made of three types of joint accounts. The most cominon class is the joint and survivorship account, which is usually opened by a depositor who instructs the bank to pay to himself or a named person or the survivor. It is customary to add additional language to the deposit card, stating that the parties mentioned in the account hold the funds as joint owners, that each has the right to withdraw and that upon the death of either the balance should be paid to the survivor. ${ }^{101}$ Sometimes the card

00 See text at note 2 supra.

100 This is best demonstrated by the cases holding that if the depositor shows that he did not intend to make a gift, the co-depositor has no claim to the funds in the account notwithstanding the form of the account. See note 111, infra.

101 Hill v. Havens, 242 Iowa 920, 48 N.W.2d 870 (1951); Cleveland Trust Co. v. Scobie, 114 Ohio St. 241, 151 N.E. 373 (1926) ; Holbrook v. Hendricks' Estate, 175 Ore. 159, 152 P.2d 573 (1944) ; Mader v. Stemler, 319 Pa. 374, 179 Atl. 719 (1935) ; Holt v. Bayles, 85 Utah 364, 39 P.2d 715 (1934). 
contains the statement that the depositors hold as joint tenants with the right of survivorship. ${ }^{102}$ Probably the importance of the additional wording has been overemphasized. It is not the form of the deposit but the depositor's intention which usually prevails. Intention may be expressed in simple language. The most important part of having the parties execute formal instruments is that the bank official who handled the transaction will remember the details, and will be able to testify in the question of the depositor's intention. It is of course necessary that a present right to withdraw be conferred on the donee. The technique is unimportant if the fact is accomplished.

Sometimes the depositor will desire to change an account held in his individual name to a joint and survivorship account. The fact that he adds another name to the account will not be sufficient to transfer an interest to the co-depositor that will survive the death of the person furnishing the funds. ${ }^{103}$ The donor must usually show his intention to transfer the present interest in the account and relinquish his exclusive dominion by having the beneficiary sign the signature cards. This shows that the donee knows of the transfer and indicates that exclusive control has been relinquished, since the form of the account gives him a present right to withdraw the funds from the account. ${ }^{104}$

The second form of joint account is most frequently termed an "Agency Account." The account is opened in the names of $A$ or $B$, or $A$ and $B$, without providing for survivorship. If no further evidence is introduced which would show the donative intent on the part of the depositor, the form of the account is deemed to indicate that an agency has been created. ${ }^{105}$ Since the agency is revoked by the depositor's death, the co-depositor niay not recover the balance remaining in the account. ${ }^{106}$ The fact that the depositor has not provided for survivorship is usually deemed to be evidence of an intention to exclude survivorship. If the survivor recovers it must be upon a showing that the depositor intended and completed a present gift of a joint interest in the account. ${ }^{107}$ Obviously, the donee cannot recover on

102 Hibbard v. Hibbard, 118 Ind. App. 292, 73 N.E.2d 181 (1947) ; Rush v. Rush, 138 N.J.

Eq. 611, 49 A.2d 238 (Ct. Err. \& App. 1946).

103 Cerny v. Cerny, 152 Fla. 333, 11 So.2d 777 (1943) ; Ogle v. Barker, 224 Ind. 489, 68 N.E.2d 550 (1946); Spark v. Brown, 167 Kan. 159, 205 P.2d 938 (1949).

104 Bowen v. Morgillo, 127 Conn. 161, 14 A.2d 724 (1940); Day Trust Co. v. Malden Sav. Bank, 328 Mass. 576, 105 N.E.2d 363 (1952); Jones v. Fullbright, 197 N.C. 274, 148 S.E. 229 (1929).

105 Liner v. Commercial Nat. Bank, 85 Ga. App. 278, 69 S.E.2d 119 (1952); Farris v. Farris Engineering Corp., 7 N.J. 487, 81 A.2d 731 (1951); Romig v. Denkel, 326 Pa. 419, 192 Atl. 657 (1937).

106 Hall v. Hall, 235 N.C. 711, 71 S.E.2d 471 (1952); In re Zellner's Estate, 316 Pa. 202,

172 Atl. 715 (1934).

107 Scriven v. Scriven, 153 Neb. 655, 45 N.W.2d 760 (1951). 
either a contract or joint tenancy theory since there is no agreement providing that the survivor is to receive the balance remaining in the account upon the death of the person furnishing the funds.

The third category consists of the so-called "P.O.D." or "Pay on Death" accounts. In lieu of the usual joint account which gives both parties the immediate right to withdraw, a depositor executes an agreement which provides that upon his death all or part of the account is to be paid to a designated person or persons. The courts are in agreement that this form is invalid because it does not transfer a present interest of any sort to the donee, ${ }^{108}$ and that it is on its face a testamentary disposition of property which must fail for lack of compliance with the statute of wills. There have been only a few cases in which this type of account has been the subject of litigation..$^{109}$ In most instances the bank refuses to open such an account, but advises the depositor that if he desires to achieve this result he must comply with the law regulating joint accounts, or he must adopt the trust form. ${ }^{110}$

\section{Rights of the Parties to the Account During Their Joint Lives}

The cases are replete with statements that the transaction which gave to the survivor an interest in the account was valid because he had received a present interest at the time the account was opened. If this principle is carried to its logical conclusion it would result in a finding that upon the opening of a jomt account the donee has a present interest. Since the formalities are the same in all these cases there would appear that a gift has been completed by the opering of the account. Notwithstanding these statements, the law is clear that the depositor may subsequently show that he had no intention to make a gift when he opened the account, ${ }^{111}$ although both he and the donee signed the signature cards expressly stating that they held the account as joint owners with the balance to be paid to the survivor.

The argument which the depositor may use to defeat the claim of the donee will vary. If the theory adopted in the particular jurisdiction follows the traditional law of gifts the depositor shows that he lacked the requisite

108 Young v. McCoy, 152 Neb. 138, 40 N.W.2d 540 (1950) ; Tucker v. Simrow, 248 Wis. 143, 21 N.W.2d 252 (1946).

109 This problem arises more frequently under the joint tenancy type bank account statutes. See note 161 infra.

110 Under the Tentative Trust only the depositor has the right to withdraw the funds during his lifetime, and it is not necessary that the beneficiary have knowledge of the trust account. RESTATEAIENT, TRUSTS, $\$ 58$ (1935).

111 Staton v. Vernon, 209 Iowa 1123, 229 N.W. 763 (1930); Bradford v. Eastman, 229 Mass. 499, 118 N.E. 879 (1918); New Hampshire Sav. Bank v. McMullen, 88 N.H. 123, 185 Atl. 158 (1936); Dempsey v. First Nat. Bank of Scranton, 359 Pa. 177, 58 A.2d 14 (1948); Peoples Sav. Bank in Providence v. Small, 65 R.I. 149, 13 A.2d 814 (1940); Plainse v. Engle, 262 Wis. 506, 56 N.W.2d 89 (1952). 
intent to make the donation, and that the account was opened for his own convenience. ${ }^{112}$ If a state follows the joint tenancy theory the opening of the account in joint survivorship form creates the presumption that the depositor intends to create a joint tenancy. Nevertheless, in all these jurisdictions following this theory, except in the state of Indiana, ${ }^{113}$ the depositor may introduce evidence to overcome the presumption of joint tenancy. ${ }^{114}$ If the depositor fails to rebut the presumption that a joint tenancy has been created by the opening of the account in joint form the donee's interest will be protected and then the question arises as to the division of the funds. ${ }^{115}$ In the absence of special circumtances each is entitled to one-half. ${ }^{116}$

At first blush, it would appear that if a state follows the contract theory the mere fact that the contract has been executed gives to the beneficiary an interest which cannot be taken from him solely because the depositor changes his nnind. This has been qualified by the Massachusetts court, the chief proponent of the contract theory. In reality the contract is only a substitute for deliver $y^{117}$ and if the donative intent is lacking the depositor has not divested himself of any of his property, notwithstanding that by the terms of the contract, the bank has been authorized to pay someone else. ${ }^{118}$

The interpretation of the joint bank account in the manner suggested in the preceding paragraphs of this section suggests the true nature of the transaction. It is a form of gift or gift of a partial interest subject to the control of the depositor during his lifetime, which becomes absolute on his death. While the name "poor man's will"119 is more frequently applied to the tentative trust rather than the joint bank account it furnishes a clue as to the nature of the latter. The power to control and the power to revoke, which are present in the joint account during the depositor's lifetime, approximate the donor's inter vivos rights when he executes a will. The differences are in the formalities, the avoidance of probate, and in the fact that a donee has some inter vivos rights in the joint account.

It should be pointed out that in at least some jurisdictions, a husband and wife may hold a joint account as tenants by the entirety, and that in

112 Bedirian v. Zorian, 287 Mass. 191, 191 N.E. 448 (1934); Loth v. Loth, 227 Minn. 387, 35 N.W.2d 542 (1949); Werle v. Werle, 332 Pa. 49, 1 A.2d 244 (1938).

113 Clausen v. Warner, 118 Ind. App. 340, 78 N.E.2d 551 (1948).

114 Kelly v. Kelly, 135 N.J. Eq. 75, 37 A.2d 288 (Prerog. Ct. 1944); Nusshold v. Kruschke, 176 Ore. 697, 159 P.2d 819 (1945); Neill v. Royce, 101 Utah 181, 120 P.2d 337 (1941). 115 Goc. v. Goc., 134 N.J. Eq. 61, 33 A.2d 870 (Ct. Err. \& App. 1943) ; State v. Gralewski's Estate, 176 Ore. 448, 159 P.2d 211 (1945).

116 Steininetz v. Steinmetz, 130 N.J. Eq. 176, 21 A.2d 743 (Ch. 1941); Schwartz v. Sandusky County Sav. \& Loan Co., 65 Ohio App. 437, 30 N.E.2d 556 (1939); Neill v. Royce, 101 Utah 181, 120 P.2d 327 (1941).

111 Bedirian v. Zorian, 287 Mass. 191, 191 N.E. 448 (1934).

118 Gibbons v. Gibbons, 296 Mass. 89, 4 N.E.2d 1019 (1936).

119 In re Edward's Estate, 140 Ore. 431,14 P.2d 274 (1932). 
accordance with the common law one party cannot destroy the estate. ${ }^{120}$ If a husband or wife withdraws the funds this will be considered an offer to destroy the estate by the entirety. ${ }^{121}$ The other spouse may accept the offer by suing for a division of the funds in the account.

\section{Rights of Creditors}

The problem that occurs most frequently im this field is that of the rights of the donee's creditors to the joint account. If the beneficiary has a present interest in the account and the right to withdraw, it would seem that his creditors should be in the same position. Actually, only one court has gone so far as to accept this reasoning. The Supreme Court of Minnesota ${ }^{122}$ has held that since the contract entitles both parties to withdraw the entire balance, the creditor of either, being subrogated to the rights of the debtor, may subject the account to the debt. The court observed that this departed from the usual practice, but that smce the parties freely entered into such a contract they were bound to accept all of its incidents.

The majority of jurisdictions that have adjudicated the point have held that a depositor may show that the account was opened for his convenience, and that it is not subject to the claims of the creditors of the donee. ${ }^{123}$ This is consistent with the view that he may revoke the gift for his own benefit. If the form of the account indicates that a joint tenancy has been created, the burden is upon the depositor to show that he did not intend to create such a relationship if he is to be free of the donee's claims. ${ }^{124}$ If the depositor is unable to rebut the presumption of joint interest the creditor of the donee may levy upon the account. ${ }^{125}$ This result is based on the reasoming that since a joint tenancy or an interest analogous to a joint tenancy is severable by the action of the parties, execution on behalf of the creditors of either of the parties acts as a severance, and the interest of the debtor becomes subject to the claims of his creditor. ${ }^{126}$ Of course, if the account is in the nature of a tenancy by the entirety it is not subject to the individual debts of the depositors. ${ }^{127}$

120 In re Griffith, 93 A.2d 920 (Del. Ch. 1953); Alcorn v. Alcorn, 364 Pa. 375, 72 A.2d 96 (1950).

121 Berhalter v. Berhalter, 315 Pa. 225, 173 Atl. 172 (1934).

122 Park Enterprise Inc. v. Trach, 233 Minn. 467, 47 N.W.2d 194 (1951).

123 Staton v. Vernon, 209 Iowa 1123, 229 N.W. 763 (1930); R. H. White Co. v. Lees, 267 Mass. 112, 166 N.E. 705 (1929) ; Kranjcec v. Belinak, 114 Mont. 26, 132 P.2d 150 (1942); Norcross v. 1016 Fifth Ave. Co., Inc., 123 N.J. Eq. 94, 196 Atl. 446 (Ch. 1938) ; Union Properties, Inc. v. Cleveland Trust Co., 152 Ohio St. 430, 89 N.E.2d 638 (1949).

124 Norcross v. 1016 Fifth Ave. Co., Inc., 123 N.J. Eq. 94, 196 Atl. 446 (Ch. 1938); Neill v. Royce, 101 Utah 181, 120 P.2d 327 (1941).

125 Dover Trust Co. v. Brooks, 111 N.J. Eq. 40, 160 Atl. 890 (Ch. 1932); American Oil

Co. v. Falconer, $136 \mathrm{~Pa}$. Super. 598, 8 A.2d 418 (1939).

126 Ibid.

127 Bostrom v. National Bank of McKeesport, 330 Pa. 65, 198 Atl. 644 (1938). However, as agent, one co-depositor may bind the other with respect to a reorganization proceeding. Madden v. Gosztonyi Sav. \& Trust Co., 331 Pa. 476, 200 Atl. 624 (1938). 
The other type of situation that frequently calls for litigation involves the effort of either the bank or one of the joint depositors to set off the joint account against the individual debt of one of the depositors. On the ground that there is no mutuality of obligation it has been held that the account could not be set off against the individual debt of one of the depositors. ${ }^{128}$

Strangely enough, there is little litigation concerning the rights of the depositor's creditors. It would appear that under the rules governing gifts, ${ }^{120}$ the transfer would not be valid if the depositor was insolvent at the time he opened the account, and that the entire account would be subject to his debts. This would not be true if the depositor is able to show that he has in fact given a half-interest to the donee. ${ }^{130}$ Normally, he makes no such claim during his lifetinie as such a statement would operate to restrict his right to use the entire account for his own purpose.

\section{Rights of Guardians}

Not infrequently one of the parties to a joint survivorship will be declared inconipetent. If the afflicted person is the donee his guardian may claim that his ward has a present interest in the account and is entitled to withdraw from the account. Sometimes the claim may be in the form of a demand by the conservator of the exclusive possession of the pass book, or the guardian may claim that the account has been terminated by the declaration of incompetency. In some instances the litigation is not finally settled until after the death of the guardian, so that the problem is further complicated by the fact of survivorship.

On the other hand, it has been held that if the guardian of an imcompetent donor can show that his ward had no intention of making a gift of the joint deposit the guardian may recover money withdrawn by the donee. ${ }^{131}$ If there has been a gift the conservator of the depositor is not entitled to exclusive possession of the bank book, ${ }^{132}$ nor can he withdraw money from the account unless it is needed for necessaries for his ward. ${ }^{133}$ For the most part the courts have stated that the guardian does not stand in the same position as the ward insofar as joint accounts are concerned, and even though the ward, if sane, could have withdrawn the entire balance and used it as he desired, an equal right is not accorded his guardian. ${ }^{134}$ If the joint

\footnotetext{
128 Nichols v. Metropolitan Life Ins. Co., 137 Ohio St. 542, 31 N.E.2d 224 (1941).

129 See Splaine v. Morrissey, 282 Mass. 217, 184 N.E. 670 (1933).

130 For the purpose of determining the rights of creditors of the depositor, the transaction should be treated as if the survivor received the balance in the account by virtue of the depositor's will.

131 Sanderson v. Howell, 121 N.J. Eq. 56, 187 Atl. 184 (Ct. Err. \& App. 1936) ; Plainse v. Engle, 262 Wis. 506, 56 N.W.2d 89 (1952).

132 Johnson v. Nourse, 258 Mass. 417,155 N.E. 457 (1927).

133 Drain v. Brookline Bank, 327 Mass. 435, 99 N.E.2d 160 (1951).

134 Coolidge v. Brown, 286 Mass. 504, 190 N.E. 723 (1934) ; Ulmer v. Society for Savings, 35 Ohio Abs. 525, 41 N.E.2d 578 (1942).
} 
depositors are husband and wife the guardian of the incompetent is not entitled to have the account partitioned, ${ }^{\mathbf{1 3 5}}$ unless there is reason, such as the irresponsibility of the legally competent party. If a joint interest in the nature of a joint tenancy has been created, a withdrawal by the competent party will terminate the joint tenancy, but will make the party withdrawing the funds liable for any amount exceeding his interest. ${ }^{136}$ It should be observed that here again the transaction is gratuitous and the determination of the rights of the parties should be based on the realities of the particular situation. If the depositor intended the gift, and the funds in the account are not needed for his maintenance if he becomes incompetent, there is no reason why his guardian should be permitted to destroy the joint interest in the account. ${ }^{13 \pi}$

\section{Rights of the Survivor}

A study of the rights of the survivor may begin with the proposition that. in every jurisdiction he will be entitled to the balance in the account, ${ }^{138}$ as against the claim of the estate, provided the depositor has complied with the requisites set forth in that particular jurisdiction for transferring property through the use of the bank account. The difficulties besetting the survivor are in the nature of the problems of proof and the effect to be given to the fact unsupported by other evidence that the depositor, during his lifetime, opened a bank account in joint and survivorship form.

In at least five jurisdictions construing the bank account statute as having been enacted not only for the purpose of protecting the bank but also to provide a rule of property ${ }^{139}$ the fact that an account is opened in joint and survivorship form raises a presumption of gift. ${ }^{140}$ The majority rule is otherwise. No gift will be inferred if a joint account has been opened by a depositor. ${ }^{141}$ In some instances the courts go so far as to hold that the bur-

135 Ulmer v. Society for Savings, 35 Ohio Abs. 525, 41 N.E.2d 578 (1942).

136 First Trust Co. of Lincoln v. Hammond, 140 Neb. 330, 299 N.W. 496 (1941); Stout v. Sutphen, 132 N.J. Eq. 582, 29 A.2d 725 (Ch. 1943).

137 See notes 132 and 133 supra. Contra: Abrams v. Nickel, 50 Ohio App. 500, 198 N.E. 887 (1935).

138 See note 96 supra.

139 See note 53 supra.

140 Shaw v. Addison, 239 Iowa 377,28 N.W.2d 816 (1948); Hall v. Johnson, 179 Minn. 428, 229 N.W. 867 (1930); Shearin v. Coleman, 201 Miss. 193, 28 So.2d 841 (1947); Rose v. Kahler, 151 Neb. 532, 38 N.W.2d 391 (1949); Estate of Staver, 218 Wis. 114, 260 N.W. 655 (1935).

141 McNabb v. Fisher, 38 Ariz. 288, 299 Pac. 679 (1931) ; Bachmann v. Reardon, 138 Conn. 665, 88 A.2d 391 (1952) ; First Nat. Bank of Thomasville v. Sanders, 33 Ga. App. 615, 127 S.E. 658 (1925); Ogle v. Barker, 224 Ind. 489, 68 N.E.2d 550 (1946); Burns v. Nolette, 83 N.H. 489, 144 Atl. 848 (1929) ; Menger v. Otero County State Bank, 44 N.M. 82, 98 P.2d 834 (1940); Munday v. Federal Bank, 195 Okla. 120, 155 P.2d 526 (1945); Ohve v. Ohve, 231 S.W.2d 480 (Tex. Civ. App. 1950). 
den is on the survivor to show that a gift has been made, ${ }^{142}$ although it has been stated by other tribunals that the transaction will be taken at its face value unless there is evidence that a gift was not intended. ${ }^{143}$

If the contract theory is followed the question arises as to whether or not oral evidence is admissable to show that the depositor opened the account for his own convenience, notwithstanding that the written contract executed by the bank and the joint payees, provided that the property was held by the depositors as joint owners, that each of the depositors has the present right to withdraw from the account and, that upon the death of either the balance shall be paid to the survivor. In at least four jurisdictions it has been held that oral evidence is madnissible to vary the written agreement for the purpose of showing that survivorship was not intended. ${ }^{144}$ The more recent cases admit evidence to show the depositor's intention or lack of intention to make a gift despite the fact that the contract recites that the parties own the account as joint owners with the right of survivorship. ${ }^{145}$ Of course, if there is undue influence, fraud or lack of capacity, parol evidence will be admitted to show these facts. ${ }^{146}$

In at least three cases the question has been raised as to whether or not evidence of the attempted disposition of the funds in the joint account, by devise in a will, is relevant to the question of the depositor's intention at the time he opened the account to make a gift. Rhode Island has held that the disposition of the account in a will is evidence that the depositor had not intended to make a gift. ${ }^{147}$ Montana $^{148}$ and $\mathrm{Ohio}^{140}$ have reached an opposite view by adopting the reasoning that a gift is made when the account is opened, and that the will is meffective for any purpose since the property is no longer in the testator's control. If the true nature of the joint bank account is recognized, it is a method of disposing of property in lieu of a will, absolute gift or trust. Mention of the account in the will should not

$142 \mathrm{McNabb}$ v. Fisher, 38 Ariz. 288, 299 P.2d 679 (1931) ; Harrington v. Emmerman, 186 F.2d 757 (D.C. Cir. 1950) ; Nashua Trust Co. v. Heghene Mosgofian, 97 N.H. 17, 77 A.2d 636 (1951) ; Industrial Trust Co. v. Scanlon, 26 R.I. 228, 58 Atl. 786 (1904). However, parol evidence is admissible to show an oral contract or the intent to make a gift. Asche v. Matthews, 136 Kan. 740, 18 P.2d 177 (1933) ; Leverette v. Ainsworth, 199 Miss. 652, 23 So.2d 798 (1945). 143 Kittredge v. Manning, 317 Mass. 689, 59 N.E.2d 261 (1945).

144 Estate of Murdoch, 238 Iowa 898, 29 N.W.2d 177 (1947) ; State Board of Equalization v. Cole, 122 Mont. 9, 195 P.2d 989 (1948); Oleff v, Hodapp, 129 Ohio St. 432, I95 N.E. 838 (1935) ; Holt v. Bayles, 85 Utah 364, 39 P.2d 715 (1935).

145 Murray v. Gadsden, 197 F.2d 195 (D.C. Cir. 1952) ; Armstrong v. O'Brien, 329 Mass. 572, 109 N.E.2d 647 (1952); see Neill v. Royce, I0I Utah 181, 120 P.2d 327 (1941).

146 Peters' Adm'r. v. Peters, 224 Ky. 493, 6 S.W.2d 499 (1928) ; Parkening v. Haffke, 153 Neb. 678, 46 N.W.2d 117 (1951) ; Steiner v. Fecycz, 72 Ohio App. 18, 50 N.E.2d 617 (1942); Wood v. Kinter, 86 Utah 279, 43 P.2d 192 (1935).

147 Old Colony Trust Co-Operative Bank v. Thurber, 68 R.I. 440, 28 A.2d 747 (1942).

148 In re Sullivan's Estate, 112 Mont. 519, 118 P.2d 383 (1941).

140 Bennett v. Bennett, 70 Ohio App. 187, 45 N.E.2d 614 (1942). 
be evidence of the depositor's intentions. No one would argue that once a donor has made an absolute gift of property that he may dispose of it in any manner by his will.

In recent years, on three reported occasions, donees have taken the life of the depositor. In Ohio ${ }^{150}$ and Pennsylvania ${ }^{151}$ the courts have stated that the contract was clear and plain, that the account becomes the property of the survivor, and that the statute which prohibits the wrongdoer from taking property by a will or intestacy, if he kills the donor, has no application. The survivor has been held to be entitled to the property. On the other hand, Minnesota ${ }^{152}$ has found that the donee's interest could have been defeated by the depositor, prior to his death, had it not been for the felonious act of the donee. By his wrongful act the beneficiary has prevented the depositor from exercising this right and thus the former should not be permitted to receive an interest in the account. Hence, the Mimnesota court has held that the survivor will not prevail as against the depositor's estate.

The question may be asked as to whether or not the rights of the survivor in all cases should be determined on the factual evidence which is introduced pertaining to the law of gifts. It should be remembered that there are three types of joint accounts. Of these three the "Pay on Death" account is invalid because of testamentary disposition. The interest of the co-depositor in the "Agency" account, the second type of joint account, terminates on the death of the depositor because the latter's death automatically revokes the agency. This type of account is suitable for those situations where the depositor desires to authorize another party to draw funds from the account solely for the purpose of serving the depositor's convenience.

It would seem that when a depositor opens a joint and survivorship account and executes signature cards which recite that the account is to be paid to either during the depositors' joint lives and to the survivor upon the death of either, a rebuttable presumption of an intent to make a gift of a joint interest should arise. After the depositor's death only evidence of fraud, undue influence or lack of capacity should be admissible to rebut the presumption. It serves no useful social purpose to encourage litigation concerning the disposition of the balance of the joint account upon the death of the depositor, when in most instances he intended, in his unlearned manner, to make a testamentary disposition of his property. If the joint account is sound, as a means of transferring property, it should be umiformly administered.

150 Oleff v. Hodapp, 129 Ohio St. 432, 195 N.E. 838 (1935).

151 Di Lallo v. Corea, 19 D. \& C. 282 (C. P. Allegheny Co. 1932).

152 Vesey v. Vesey, 54 N.W.2d 385 (Minn. 1952). 
THE LAW OF JOINT ACCOUNTS IN STATES HAVING JOINT TENANCY

BANK ACCOUNT STATUTES

\section{Function of the Joint Tenancy Statute}

It was early argued that the joint bank account statute, which provides that a deposit made in the name of two or more persons and payable to either or the survivor shall become the property of such depositors as joint tenants, was enacted for the sole purpose of protecting the bank. This view has been rejected by all of the tribunals which have construed such an enactment ${ }^{153}$ on the ground that it was the legislative intent not only to protect banks in the payment of deposits but also to fix the ownership of the funds of the persons named as joint tenants. Had the purpose of the act been only to protect banks there would be no meaning to the part of the act stating that certain deposits made in the name of two or more persons shall be deemed to be owned by them in joint tenancy. ${ }^{154}$

The statutes are stated in the present tense. The courts agree that from the opening of the account in the statutory form, unexplained by other competent evidence, there arises the presumption of a gift of a joint interest, and that all of the incidents attached to joint tenancy, including the right of survivorship, come into existence. ${ }^{155}$ It is important to note that the presumption is created by the act of the depositor in opening the account in joint and survivorship form. As will be demonstrated in the discussion of the rights of the parties during their joint lives and of the rights of creditors, evidence may be admitted to show that the parties did not in fact create a joint tenancy, notwithstanding that the deposit was made in statutory form. ${ }^{156}$

\section{Formal Requisites}

A discussion relating to formal requisites must be viewed in the light of the common law rule that the opening of a bank account in joint and survivorship form does not create a presumption of a gift. ${ }^{157}$ The co-depositor is said to have acquired an interest in the account by the mere fact that the deposit was made in the joint form only if the bank account statute is con-

153 Pye v. Higgason, 210 Ark. 347, 195 S.W. 2 d 632 (1946) ; Solon v. Lichtenstein, 39 A.C. 77, 244 P.2d 905 (1952); In re Rehfeld's Estate, 198 Mich. 249, 164 N.W. 372 (1917); Clevidence v. Mercantile Home Bank, 355 Mo. 904, 199 S.W.2d 1 (1947); Moskowitz v. Marrow, 251 N.Y. 380, 167 N.E. 506 (1929); Winner v. Carroll, 169 Wash. 208, 13 P.2d 450 (1932).

154 Houle v. McMillan, 83 Colo. 216, 263 Pac. 409 (1928).

155 Maahs v. Maahs, 307 Mich. 549, 12 N.W.2d 335 (1943); Commerce Trust Co. v. Watts, 360 Mo. 971,231 S.W.2d 817 (1950); In re Peterson's Estate, 182 Wash. 29, 45 P.2d 45 (1935); Marrow v. Moskowitz, 255 N.Y. 219, 174 N.E. 460 (1931).

156 See note 171 infra.

157 See note 141 supra. 
strued as a rule of property ${ }^{158}$ or if the statute, pertaining to joint accounts, expressly provides that the opening of the account in joint form shall create a joint tenancy. In view of the holding that the depositor acquires his rights only through the joint tenancy bank account statute, it is necessary that he comply with the statute in order to bring the account within its purview. Failure to open the account in the so-called statutory form has resulted in a great deal of litigation.

All of the joint tenancy type enactments provide that the account must be opened in two names. If the parties have a nunber of separate accounts held in their individual nanies they nuay not avail themselves of the provisions of the statute, whatever their intent may be. ${ }^{159}$ On the other hand, if they sign the signature card providing that the account is to be paid to either or the survivor, the account is deemed to be a statutory joint account, and all of the incidents arising from the creation of this form of deposit conre into being. ${ }^{100}$

Three basic problems are involved in the nuatter of the fornal requisites relating to the statutory joint tenancy account. The most common source of litigation is the account opened in the nanie of two persons, either in the disjunctive or conjunctive, which does not provide for payment to the survivor. In the majority of states having the joint tenancy type statute there have been controversies dealing with this problem. The courts have consistently held that if the account does not in any nianner provide for survivorship the account is not one which in forn is to be paid to either or the survivor, and consequently does not come within the statute. ${ }^{161}$ If a provision is made for survivorship, providing that both the parties have a present right to withdraw, there has been a conpliance with the statute and the survivor will be entitled to the funds, although there may be variation in the language used to achieve this result. ${ }^{162}$

The second type of difficulty that arises under this type of statute is

\footnotetext{
158 See notes 53-58 supra.

150 Harbour v. Harbour, 207 Ark. 551, 181 S.W.2d 805 (1944).

160 Estate of Gaine, 15 Cal. 2d 255, 100 P.2d 1055 (1940); Powell v. Pennock, 198 Mich. 573, 165 N.W. 799 (1917); Matter of Fenelon, 262 N.Y. 57, 186 N.E. 201 (1933); Winner v. Carroll, 169 Wash. 208, 13 P.2d 450 (1932).

161 Betker v. Ide, 335 Mich. 291, 55 N.W.2d 835 (1952); Murphy v. Wolfe, 329 Mo. 545, 45 S.W.2d 1079 (1932) ; Brumer v. Brumer, 223 App. Div. 186, 228 N.Y. Supp. 63 (3d Dep't 1928); In re Grace's Estate, 138 Misc. 348, 247 N.Y.S. 224 (Surr. Ct., 1930), aff'd, 232 App. Div. 785, 249 N.Y. Supp. 862 (4th Dep't 1931) ; McDermott v. Bennett, 253 App. Div. 580, 5 N.Y.S.2d 4 (4th Dep't 1938), aff'd, 279 N.Y. 579, 17 N.E.2d 448 (1938); In re Raner's Will, 113 N.Y.S.2d 355 (Surr. Ct. 1952) ; Tacoma Savings \& Loan Association v. Nadham, 14 Wash. 2d 576, 128 P.2d 982 (1942).

162 Equitable \& Central Trust Co. v. Zdziebko, 260 Mich. 366, 244 N.W. 505 (1932); In re Carlin's Estate, 134 Misc. 596, 236 N.Y.Supp. 329 (Surr. Ct. 1929); In re Gallagher's Estate, 146 Misc. 112, 262 N.Y. Supp. 381 (Surr. Ct. 1932) ; In re Lo Palo, 253 App. Div. 132, 2 N.Y.S.2d 397 (4th Dep't 1937), aff'd, 279 N.Y. 692, 18 N.E.2d 317 (1938).
} 
with an account that provides that during the depositor's life it is to be paid to him, and upon his death it is to be paid to a named individual or individuals in whole or in part. ${ }^{163} \mathrm{~A}$ typical case is the First National Bank and Trust Company in Pontiac v. Huntley ${ }^{164}$ in which the depositor had the following language added to his signature card: "In case of death or sickness money to go to son." The court observed that this was not a deposit made in the manner required by the statute, and that consequently the survivor was not entitled to the proceeds. Cases adjudicated in other jurisdictions have reached the same result. ${ }^{165}$ This result would seem to be sound, for inasmuch as the bank account statute is in effect a new mode of transferring property, it is not unreasonable to require a strict compliance with the procedures provided therein.

The third source of litigation is the opening of an account in joint and survivorship form by a depositor who does not know, or who does not understand, the legal implications involved in his act. In such situations it has been held that the account is not opened in statutory form. ${ }^{166}$ As stated by the New York court: "It is the making of the deposit in statutory form which controls. How then is that accomplished? We think the deposit is made when the initial moneys are paid over with instructions to credit the same in a certain form, and the deposit is accepted and credited, as directed." 167

The New York court goes on to say that a depositor must intend to provide for survivorship. If he does not instruct the bank to open the account in this form it is not a statutory account, notwithstanding that the bank may stamp on the withdrawal slip and on the ledger sheet the magic words: "Payable to either or the survivor." Of course, if the depositor intends to open the account in statutory form the survivor will be entitled to the funds upon the death of the former, notwithstanding that the account was opened solely as a matter of convenience. ${ }^{16 s}$

It is necessary that all of the formalities be completed prior to the death of the depositor. If the initial deposit has never been paid so that the bank does not have funds in the account, ${ }^{169}$ or, if the donee does not return the

${ }^{163}$ In this transaction the donee may not make withdrawals during the depositor's lifetimc. 164251 Mich. 483, 232 N.W. 192 (1930).

165 Mercantile Bank v. Haley, 179 S.W.2d 916 (Mo. App. 1944); Edmonds v. Perry, 62 Nev. 41, 140 P.2d 566 (1943) ; Hayes v. Claessens, 234 N.Y. 230, 137 N.E. 313 (1922); McDonald v. Sargent, 121 Misc. 437, 201 N.Y. Supp. 129 (Sup. Ct. 1923).

166 Blum v. Blum, 11 Cal. App. 2d 210, 53 P.2d 397 (1936); Mineau v. Boisclair, 323 Mich. 64, 34 N.W.2d 556 (1948).

167 Matter of Fenelon, 262 N.Y. 308, 311, 186 N.E. 794, 795 (1933).

168 Munson v. Haye, 29 Wash. 2d 733, 189 P.2d 464 (1948).

169 In re Lo Palo, 253 App. Div. 132, 2 N.Y.S.2d 397 (4th Dep't 1937), aff'd, 279 N.Y. 692, 18 N.E.2d 317 (1938). Contra: Klindera v. Smith, 15 Cal. App. 2d 115, 59 P.2d 156 (1936). 
signature cards properly executed prior to the depositor's death, ${ }^{170}$ the account is not a statutory one and the survivor may not recover the balance remaining at the donor's death as a survivor to a statutory joint tenancy.

\section{Rights of the Parties During Their Joint Lives}

A literal reading of the statute would lead one to believe that upon the opening of an account in statutory form the donee acquires an immediate half-interest in the account, with the attendant right of survivorship; for the statute provides that upon opening the account in the stated form the deposit is held by the parties as joint tenants. The cases hold to the contrary. This is accomplished by either one of two approaches. One line of cases holds that while the depositor has made a gift he has the power of revocation, so that during his hife he may terminate all of the co-depositor's interest in the account. ${ }^{171}$ The other theory is based on the premise that the opening of the account in joint and survivorship form merely raises a presumption of a gift in joint interest, and during the depositors' joint lives the person furnishing the funds may show that he in effect did not intend to create a joint tenancy, notwithstanding that the account was opened in joint form. ${ }^{172}$ Regardless of which of the two views the court adopts the result is the same in all states: during the depositors' joint lives the form of the deposit is not conclusive on the fact of ownership.

It is clear under either theory that the opening of the account in the statutory form raises a presumption of a gift of a joint interest. But this presumption has been described as being a weak one that readily yields to the parol proof as to the real intention of the depositor. ${ }^{173}$ If a joint tenancy has actually been created the donee acquires an interest that may not be divested by the withdrawal of all the funds in the account by the depositor. ${ }^{174}$

The rights of the parties during their joint lives have been often litigated in the state of New York. It has been there adjudged that when an account is opened in the form prescribed by the statute there arises a statutory presumption of joint tenancy. ${ }^{175}$ Withdrawal of the money does not destroy

170 Burns v. Plaza Bank of Commerce, 141 S.W.2d 209 (Mo. App. 1940) ; Munson v. Haye, 29 Wash. 2d 733, 189 P.2d 464 (1948).

171 Rasey v. Currey's Estate, 265 Mich. 597, 251 N.W. 784 (1933) ; Esling v. City Nat. Bank \& Trust Co., 278 Mich. 571, 270 N.W. 791 (1936).

172 Patterson v. Comastri, 39 A.C. 68, 244 P.2d 902 (1952); McGuire v. Crockett, 112 Colo. 552, 151 P.2d 326 (1944); Marrow v. Moskowitz, 255 N.Y. 219, 174 N.E. 460 (1931); In re Porianda's Estate, 256 N.Y. 423, 176 N.E. 826 (1931) ; Munson v. Haye, 29 Wash. 2d 733, 189 P.2d 464 (1948).

1 173 Ambruster v. Ambruster, 326 Mo. 51, 31 S.W.2d 28 (1930).

174 In re Kellogg, 41 Cal. App. 2d 833, 107 P.2d 964 (1940); Ruch v. First Nat. Bank of Three Rivers, 326 Mich. 52, 39 N.W.2d 240 (1949).

175 Marrow v. Moskowitz, 255 N.Y. 219, 174 N.E. 460 (1931). 
the joint tenancy, ${ }^{176}$ but opens the door to competent evidence showing that no joint tenancy was originally intended. ${ }^{177}$ If a joint tenancy has in effect been created, the joint tenant has the immediate right to withdraw moiety or less for his own use. ${ }^{178}$ If either party withdraws more than his share he is under a duty to account to his co-tenant, ${ }^{170}$ but if the depositor did not intend to establish a joint tenancy, the surviving donee acquires no rights in the money withdrawn by the depositor. ${ }^{180}$ In the latter instance, evidence of the donor's intention is admissible even in a proceeding brought subsequent to his death. ${ }^{181}$

In recent years there have been a number of cases concerning the rights of the husband and wife to the proceeds of the joint account following their legal separation. It may be shown that they had no intention to create a joint tenancy despite the fact that the account was opened in statutory form. If this be true the proceeds will be divided in accordance with the realities of ownership. ${ }^{182}$ If a joint tenancy has been created then the parties will be entitled to half-interest in the account, ${ }^{183}$ the presumption being that the spouse furnishing the funds intended to make a gift of half of the account. ${ }^{184}$

It should be observed that in two of the states having a joint tenancy type of statute it is possible for the husband and wife to create a tenancy by the entirety. ${ }^{185}$ During the parties' joint lives the rules governing tenancies by the entireties will be applied to terminate their respective interest in the account.

\section{Rights of Creditors}

If, as between the parties, evidence is available to show that a joint tenancy is not intended it logically follows that the same rule applies when creditors of either claim the account. It has been held that while both parties

176 O'Connor v. Dunnigan, 158 App. Div. 334, 143 N.Y.Supp. 373 (3d Dep't 1913); In re Porianda's Estate, 256 N.X. 423, 176 N.E. 826 (1931).

175 Marrow v. Moskowitz, 255 N.Y. 219, 174 N.E. 460 (1931); In re Juedal's Estate, 280 N.Y. 37, 19 N.E.2d 671 (1939); Walsh v. Keenan, 293 N.X. 573, 59 N.E.2d 409 (1944).

178 In re Juedel's Estate, 280 N.Y. 37; 19 N.E.2d 671 (1939).

179 In re Suter's Estate, 258 N.Y. 104, 179 N.E. 310 (1932).

180 Walsh v. Keenan, 293 N.Y. 573,59 N.E.2d 409 (1944); Chazin v. Chazin, 60 N.Y.S.2d 744 (Sup. Ct. 1946).

181 See note 172 supra.

182 Glaser v. Glaser, 37 N.Y.S.2d 477 (Sup. Ct. 1942), aff'd, 264 App. Div. 884, 36 N.Y.S.2d 878 (2d Dep't 1942); Central Hanover \& Trust Co. v. Van Nyevelt, 70 N.Y.S.2d 622 (Sup. Ct. 1947); Stark v. Central Sav. Bank, 93 N.Y.S.2d 805 (Sup. Ct. 1949); Stevens v. Stevens, 115 N.Y.S.2d 49 (Sup. Ct. 1952).

${ }^{183}$ Loker v. Edmans, 204 App. Div. 223, 197 N.Y. Supp. 857 (3d Dep't 1923) ; In re Ekins, 126 Misc. 1, 213 N.Y. Supp. 162 (Sup. Ct. 1925).

184 In re Ekins, 126 Misc. 1, 213 N.Y. Supp. 162 (Sup. Ct. 1925); Michaels v. Michaels, 69 N.Y.S.2d 668 (N.Y. City Ct. 1946).

185 Cross v. Pharr, 215 Ark. 463, 221 S.W.2d 24 (1949); Cullum v. Rice, 236 Mo، App. 1113,162 S.W.2d 342 (1942). 
are alive either has the right to establish the real fact with reference to his interest in the account as to the claims of the creditor of his co-depositor. ${ }^{180}$ The depositor furnishing the funds may show, as against the claim of the creditor of the co-depositor, no intention to create a joint tenancy so that there exists no interest in the co-depositor subject to levy. ${ }^{187}$ Consistent with this principle is the holding that the creditor of the depositor may show that the account was created for convenience only, and that the entire balance is subject to the claim of the depositor's creditors. ${ }^{188}$ Of course, if the bank account is held in joint tenancy it is severable for the purpose of ineeting the demands of the creditors. ${ }^{189}$ Each of the depositors has a half-interest which may be levied on for the purpose of meeting his obligation to his creditors. ${ }^{100}$

Adopting a more realistic approach the Michigan Supreme Court has held that a bank account held in joint tenancy is severable for the purpose of meeting the demands of creditors, and that in the absence of proof establishing contributions towards the deposits the presumption is that each contributed one-half. However, this presumption may be rebutted, and upon showing that one party furnished all the funds the entire balance would be subject to his debts. ${ }^{191}$

If the person furnishing the funds has the right to revoke, which apparently he does in most jurisdictions, the entire account should be subject to his obligations. Any other approach works a prejudice against the depositor's creditors. If the depositor can revoke the gift then his creditors ought to be able to subject the account to his lawful claims. Neither the co-depositor nor his creditors are harmed, for it should not make any difference to them whether the party furnishing the funds, or his creditors, terminate the joint account.

\section{Rights of Guardians}

There have been relatively few cases dealing with the question as to what happens when either of the parties in joint accounts is declared incompetent. It has been held that if a joint tenancy has in fact been created it is not destroyed by the incompetency of the depositor, ${ }^{192}$ and that upon the death of the depositor the survivor is entitled to the funds against the

180 Spear v. Farwell, 5 Cal. App. 2d 111, 42 P.2d 391 (1935); Schnur v. Dunker, 38 S.W.2d 282 (Mo. App. 1931); Gluck v. Flathush Sav. Bank, 45 N.Y.S.2d 624 (Sup. Ct. 1943).

187 Schnur v. Dunker, 38 S.W.2d 282 (Mo. App. 1931).

188 Spear v. Farwell, 5 Cal. App. 2d 111, 42 P.2d 391 (1935).

180 Murphy v. Michigan Trust Co., 221 Mich. 243, 190 N.W. 698 (1922).

190 In re Hoffman's Estate, 175 Misc. 607, 25 N.Y.S.2d 339 (Surr. Ct. 1940); Sitomer v. North River Savings Bank, 196 Misc. 870, 95 N.Y.S.2d 402 (N.Y.City Ct. 1949).

191 Murphy v. Michigan Trust Co., 221 Mich. 243, 190 N.W. 698 (1922).

192 Doran v. Hibernia Savings \& Loan Society, 80 Cal. App. 2d 790, 182 P.2d 630 (1947). 
claims of the former's administrators ${ }^{193}$ However, if the incompetent depositor opened the account merely for his own convenience, ${ }^{104}$ or to provide for survivorship without transferring the present interest, ${ }^{195}$ a joint tenancy has not been created, and the committee of the incompetent donor is entitled to the balance in the account remaining at the depositor's death. Furthermore, upon rebutting the statutory presumption, the committee nray recover funds withdrawn by the donee. ${ }^{106}$ Where the property has been held in the name of the husband and wife in the statutory form, and one spouse has appointed a committee for the other, upon the death of the committee the account becomes the sole property of the incompetent. ${ }^{197}$

There being no defimitive cases on the rights of the parties in the incompetency situation the way is clear for the courts to outline a realistic policy. It would seem that if the depositor becomes incompetent his committee should be entitled to the funds in the account, at least to the extent that it is necessary to use them for the purpose of maintaining the incompetent. If it is not necessary to use the joint account because there is ample property of other types, the committee should not be entitled to use any of the joint account. If the donee is incompetent his conmittee should not be entitled to any of the proceeds in the account as against the claims of the competent depositor, unless a statutory joint tenancy was intended at the time the account was opened. Certainly the conmittee should not be in a better position than the donee who, if competent, could not prevail against the depositor who revokes the gift.

\section{Rights of the Survivor}

For the purpose of describing the rights of the survivor it is necessary to distinguish between two kmds of joint tenancy bank statutes. The one type of statute provides that the opening of the account in joint survivorship form creates a presuniption of joint tenancy, which becomes conclusive upon the death of the depositor. ${ }^{198}$ The other kind of statute is silent on the issue of presumptions. ${ }^{199}$ The latter statutes are construed to create a rebuttable presumption of joint tenancy, which nray be overcome by the introduction of convincing evidence. ${ }^{200}$ It is interesting to note that the Cali-

193 Doran v. Hibernia Savings \& Loan Society, 80 Cal. App.2d 790, 182 P.2d 630 (1947);

Gardner v. Henderson, 35 N.Y.S.2d 439 (Sup. Ct. 1942).

104 Gluck v. Flatbush Sav. Bank, 45 N.Y.S.2d 624 (Sup. Ct. 1943).

195 Pendley v. Pendley, I63 Misc. 571, 298 N.Y. Supp. 311 (Surr. Ct. 1937).

196 Gibbons v. Schwartz, 261 App. Div. 794, 27 N.Y.S.2d 214 (1st Dep't 1941), aff'd, 288

N.Y. 612, 42 N.E.2d 611 (1942).

${ }^{107}$ In re Peters, 50 N.Y.S.2d 573 (Sup. Ct. 1944).

198 See note 66 supra.

${ }^{199}$ See note 65 supra.

200 Mitts v. Williams, 319 Mich. 417, 29 N.W.2d 841 (1947); Simon v. St. Louis Union Trust Co., 346 Mo. 146, 139 S.W.2d 1002 (1940); In re Fickmott's Estate, 256 App. Div. 1047, 10 N.Y.S.2d 918 (4th Dep't 1939); Gaylord v. Gaylord, 271 App. Div. 1045, 68 N.Y.S.2d 514 (3d Dep't 1947). 
fornia statute currently contains no provision pertaining to the effect of creating a presumption to be given the opening of an account in joint and survivorship form, although prior statutes had contained a provision patterned after the New York conclusive presumption clause. ${ }^{201}$

Both types exist in New York. If the statutory joint and survivorship account is opened in a savings bank the presuniption of an intention to establish a joint tenancy becomes conclusive on the death of the depositor. If the same account is opened in any banking institution other than a savings bank, the presumption of joint tenancy is rebuttable, so that oral evidence is admissible, even after the depositor's death, to show his intention in opening the account. ${ }^{202}$

Regardless of the type of statute it is everywhere agreed that the presumption of joint tenancy may be rebutted upon the showing of fraud, undue influence or nicompetency. ${ }^{203}$ The burden is upon the person claiming these facts, ${ }^{204}$ and the allegations of fraud or undue influence without supporting facts are inere conclusions of law, and are insufficient to rebut the statutory presumption of joint tenancy. ${ }^{205}$

The Michigan courts, which depart from the general rule, hold that if the fact of joint ownership is contested the statute has no weight as evidence, and it is necessary that the donee show that a gift of a joint interest has been made. ${ }^{206}$ Contrasted with the Michigan holding are the California $^{207}$ and Missouri decisions, ${ }^{208}$ to the effect that if the account is opened by reason of a formal instrument executed by the parties, evidence is inadmissible to show that the depositor opened the account only for his own convenience on the ground that such evidence violates the parol evidence rule. However, it may be shown that even though the survivor obtains an interest by reason of the statutory joint tenancy, he may be held to hold the property in trust by reason of an understanding with the depositor. ${ }^{209}$

In at least three jurisdictions the question has arisen as to whether or not the survivor is entitled to the funds in a statutory joint account if he has

201 In re Gaines' Estate, 15 Cal.2d 255, 100 P.2d 1055 (1940); CAL. BANK Code $\$ 852$.

202 In re Jagodzinska's Estate, 272 App. Div. 660 , 74 N.Y.S.2d 628 (4th Dep't 1947).

203 Solon v. Lichtenstein, 39 A.C. 77, 244 P.2d 905 (1952); Gordon v. Erickson, 356 Mo

272, 201 S.W.2d 404 (1947); In re Bush's Estate, 195 Wash. 416, 81 P.2d 271 (1938).

204 In re Witter's Will, 270 App. Div. 407, 60 N.Y.S.2d 606 (3d Dep't 1946) ; In re Jagodzinska's Estate, 272 App. Div. 660, 74 N.Y.S.2d 628 (4th Dep't 1947).

${ }^{205}$ Massey v. Cullen, 145 Misc. 655, 260 N.Y. Supp. 120 (Sup. Ct. 1932); In re Conover's Estate, 163 Misc. 599, 297 N.Y. Supp. 577 (Surr. Ct. 1937), aff'd, 252 App. Div. 917, 300 N.Y.S. 1357 (4th Dep't 1937).

206 Allstaedt v. Ochs, 302 Mich. 232, 4 N.W.2d 530 (1942); Mitts v. Williauns, 319 Mich. 417, 29 N.W.2d 841 (1947).

207 In re Gaines' Estate, 15 Cal.2d 255, 100 P.2d 1055 (1940).

208 Counmerce Trust Co. v. Watts, 360 Mo. 971, 231 S.W.2d 817 (1950).

209 Jarkieh v. Badagliaicco, 75 Cal. App. 2d 505, 170 P.2d 994 (1946). 
unlawfully taken the life of his co-tenant. The Colorado Supreme Court ${ }^{210}$ has held that no limitation has been placed by the legislature on the joint tenant's right to the whole interest, and that once a joint tenancy has been created the survivor may recover the funds on deposit. Missouri and New York have held otherwise. The Missouri controversy involved an account held by a husband and wife. The murder severed the estate by the entirety, making them tenants in common, and the husband was held to be a trustee of one-half of the proceeds in the account for the estate of his wife. ${ }^{211}$ The New York courts have declared it to be "abhorrent to all the rules to equity and justice to permit ... this murderer to retain title to this money under the circumstances." 212 This tribunal would not allow the wrongdoer to profit by his felomous act.

\section{Rights of the Surviving Wife}

That New York is the only jurisdiction in which this problem appears to have arisen may be explained by the fact that New York has gone further than most states in protecting the surviving widow. The highest court there has held that the banking statute has provided for a lawful and convenient method for the transferring of property, and that the making of the deposit is conclusive evidence of an intention to vest title. It was adjudicated that the widow was not entitled to any funds in the account held by her decedent husband and a third party survivor. ${ }^{213}$ While at first glance it would seem that the wife should not be barred when the husband had the power to revoke the gift during his lifetime, a more thorough analysis indicates that the New York decisions are correct. The opening of the account in joint and survivorship form raises the presumption of a gift. If the donor does not revoke, the presumption becomes conclusive on his death and the gift has been perfected.

Another type of controversy that raises the question of the rights of the surviving spouse is the situation produced by a contract executed by husband and wife in which they agree to make a certain disposition of their respective estates. Usually each party will agree to leave his estate to the other, with the understanding that the survivor is to provide by will for distribution of a certain percentage of the proceeds to the decedent's relatives. Whether or not a joint account held by one of the spouses and a third party should be subject to the contract will depend upon all of the circum-

210 Smith v. Greenburg, 121 Colo. 417,218 P.2d 514 (1950).

211 Barnett v. Couey, 224 Mo. App. 913, 27 S.W.2d 757 (1930).

212 In re Santourian's Estate, 125 Misc. 668, 212 N.X. Supp. 116 (Surr. Ct. 1925); Bierbrauer v. Moran, 244 App. Div. 87, 279 N.X. Supp. 176 (4th Dep't 1935).

213 Inda v. Inda, 288 N.Y. 315, 43 N.E.2d 59 (1942); Hart v. Hart, 81 N.X.S.2d 764 (Sup. Ct. 1948). 
stances. ${ }^{214}$ The principal question is whether or not the parties actually intended that the property held in the joint account should be subject to the contract. If the money is placed in this account to defeat the intention of either of the parties the contract will prevail. ${ }^{215}$

THE LAW OF JOINT BANK ACCOUNTS IN STATES WITH SPECIAI

\section{BANK ACCOUNT STATUTES}

\section{Function of the Statutes}

In a prior paragraph ${ }^{216}$ the special statutes enacted in five jurisdictions were analyzed in the light of the case law in the respective jurisdictions. While the language of the enactment varies it would appear that in at least three of the states ${ }^{217}$ the purpose of the statute is to permit a person to open a joint bank account in survivorship form, retain control over the account and provide for payment to the survivor. It is immaterial that the depositor has not complied with any of the common law methods for transferring property. By enacting such statutes the legislatures recognize what the courts have been unwilling to concede, ${ }^{218}$ namely, that the bank account transaction does not fit into any of the accepted techniques for transferring property.

\section{Formal Requisites}

Special attention is directed to the Illinois statutes, ${ }^{219}$ which in effect provide that the instrument that establishes the rights of the survivor must be signed by both parties. Failure to obtain such a writing will result in a finding that the account is not opened in statutory form, and that the survivorship has not been created. ${ }^{220}$ Vermont $^{221}$ has a similar provision, requiring the order to pay to either depositor or the survivor to be in writing.

In Alabama, Maine and Vermont the statute provides that certain consequences will result from the opening of the account in the name of two or more persons, payable to either or the survivor. If the account is thus opened in Maine or Vermont it has been stated that a valid gift is conclu-

\footnotetext{
${ }^{214}$ In re Glen's Estate, 247 App. Div. 518, 288 N.Y.S. 24 (1st Dep't 1936), aff'd, 272 N.Y. 530, 4 N.E.2d 433 (1936).

215 In re Sterling's Estate, 264 App. Div. 308, 35 N.Y.S.2d 399 (2d Dep't 1942), aff'd, 290 N.Y. 820, 50 N.E.2d 234 (1943).

216 See note 82 supra.

217 ALA. Code, tit. 5 \$ 128 (2a) (Supp. 1949), as amended by Laws 1945, p. 354; ME. REv. STAT. c. $55 \$ 36$ (1944), as amended by P. L. 1949, c. 24, p. 23; VT. REv. Stats. $\$ 8780$ (1947). 218 See text at note 96 supra. Introductory discussion, The Common Law of Joint Bank Accounts.

219 Irr. Rev. Srar. c. 76 \$ 2 (1951).

220 In re Wilson's Estate, 404 Ill. 207, 88 N.E.2d 662 (1949); Doubler v. Doubler, 412 II. 597, 107 N.E.2d 789 (1952).

221 Vr. REv. STAT. $\$ 8780$ (1947).
} 
sively presumed. ${ }^{222}$ In at least one state the depositor can avail himself of the benefit of the statute, with respect to accounts opened prior to the effective date of the enactment, by filing a declaration of his intent to bring the account within the purview of the statute. ${ }^{223}$

\section{Rights of the Parties During Their Joint Lives}

In only one jurisdiction has litigation arisen from a dispute between the parties during their joint lives. The Illinois court has indicated that parties may show a limitation on the use of the account during the depositors' lifetime, and if the deposit is withdrawn contrary to the donor's instructions, a trust will be declared as to the amount withdrawn. ${ }^{24} \mathrm{It}$ is significant to note that the Alabama statute expressly reserves in the depositor control over the account during his lifetinne. ${ }^{225}$

Since the statutes place no limitation on the control over the account by the party furnishing the funds this would appear to be legislative acquiescence to the general rule that the depositor may show that he did not intend a gift or a joint tenancy, notwithstanding the form of the account. ${ }^{226}$ To Irold otherwise would defeat the purpose of the statute, for its aim is to permit the donor to retain control over the gift during his lifetime.

\section{Rights of Creditors}

The paucity of litigation under the special joint bank account statutes is demonstrated by the fact that only one case has arisen which involved the rights of the creditors. The Supreme Court of Alabama held that a donee making no contribution has no present interest subject to the claims of his creditors during the depositor's lifetmie. ${ }^{227}$ The same theory is adopted by the New Jersey enactment, ${ }^{228}$ which states that nothing in the enactment impairs the rights of the creditors of either depositor. This would seem to require a construction that if a depositor furnished all of the funds the account would be subject to his debts. If the donee has furnished none of the funds the account would not be subject to his obligations unless he had received an interest in the account in the form of a joint tenancy.

Since the basic philosophy of these special statutes appears to be that the joint account is in form a gift, the law of gifts should be applied to de-

222 Appeal of Bosworth, 145 Me. 92, 72 A.2d 451 (1950); Patch v. Squires, 105 Vt. 405, 165 Atl. 919 (1933).

223 ME. REv. STAT. c. $55 \$ 36$ (1944), as amended hy P.L. 1947, c. 378 \$ 79 III.

224 Swofford v. Swofford, 327 Ml. App. 55, 63 N.E.2d 615 (1945).

225 AtA. Cone tit. 5 \$ 128(2a) (Supp. 1949), as amended by Laws 1945, p. 354.

226 See note 116 stıpra.

227 First Nat. Bank of Birmingham v. Hammel, 252 Ala. 624, 42 So.2d 459 (1949).

228 N.J. Stat. ANw. \& 17:9A-216 (Supp. 1952). 
termine the rights of the creditors. If the depositor still has dominion over the account then the balance should be subject to his debts to the extent that he has furnished proceeds for the account. Upon the death of the depositor the rights of his creditors should be cut off unless he is insolvent or unless there is fraud. In this respect, the special account statute should be construed the same as the joint tenancy type bank account statute.

\section{Rights of Guardians}

It has been held that the conservator of the depositor has the same rights as the depositor to withdraw the funds from the account, and that the party who did not furnish the funds has no right in the account as against the depositor's conservator. ${ }^{229}$ Since there has been only one case on the rights of creditors, no generalization may be drawn. It may be noted that this case goes further than do the cases arising under the joint tenancy type bank account statute. ${ }^{230}$ Usually the conservator may withdraw the funds only if necessary for his ward's maintenance. However, there is much to be said for the view outlined above inasmuch as the depositor's conservator could be considered to stand in his ward's shoes, possessing all of the ward's rights. It would be logical to give the depositor's guardian more control under the special statute than under the joint tenancy statute, for in the latter situation the donee is presumptively a joint tenant during the donor's lifetime. Under the special statute he has no present right.

\section{Rights of the Survivor}

The Alabama enactment provides that the account shall become the property of the survivor upon the death of the party furnishing the funds. ${ }^{231}$ This accomplishes the same effect as the Vermont statute, ${ }^{232}$ which provides that the use of the words "payable to either or the survivor" in the account order furnisles conclusive evidence as between the payees or their legal representative of the creation of an absolute joint account. The Vermont statute does not apply where fraud, undue influence or incapacity is shown.

It has been held that if the depositor did not realize the nature of the instrument he was signing, when he created the joint account agreement, the transaction will not come within the statute. ${ }^{233}$ This fits in with the general rule applied to joint accounts. If the account has not been opened in

220 Manta v. Kahl, 348 Ill. App. 313, 108 N.E.2d 781 (1952).

${ }^{230}$ See note 186 supra.

231 See note 225 supra.

232 See note 221 supra.

233 William's Estate v. Tuch, 313 Ill. App. 230, 39 N.E.2d 695 (1942). 
accordance with the statute, the survivor will not prevail as against the widow. ${ }^{234}$

In the one controversy, involving the effect of the murder of the depositor by the donee, it was held under the Illinois statute that the survivor takes by survivorship in joint tenancy and not by descent. The survivor was held to be entitled to the funds and the courts rejected the claim that she held the funds in constructive trust for the estate of the deceased. ${ }^{235}$

THE NEED FOR RE-EXAMINATION OF THE JOINT BANK ACCOUNT IAWS

\section{Interest Involved in the Joint Bank Account}

"The increasing use of joint bank accounts makes the problem before us one of general importance," observed the Oregon Supreme Court while determining the rights of a survivor to a joint bank account. "The fact that upon the death of the husband the sum is at once available to discharge the expense of the last illness and provide for household necessities, without court proceedings, has won for such accounts increasing fame. In fact, these accounts are regarded by people in modest circumstances as a poor man's will." 236

While one may readily agree that the problem involved in joint bank accounts is of great importance, the Oregon tribunal has somewhat oversimplified the transaction. Not only is the depositor concerned with providing funds to meet the expenses of his last illness and to take care of the household, but also the bank, the creditors, and the state itself have an interest in the joint account.

Upon examining the aforementioned interests, it will be found that the bank is concerned with the consequences that arise from the opening of the account in joint form because it must make an election as to whether it will pay the funds to the survivor or deliver them to the depositor's estate. If it can pay to either without determining the ultimate rights of the claimants, the bank has all the protection that it needs. If it does not have such assurance it will not authorize joint accounts.

The depositor has an interest not only because he furnishes the money

234 Hamilton v. First State Bank of Willow Hill, 254 Ill. App. 55 (1929). If the account is in statutory form, and there is no fraud, the survivor prevails over the spouse. Patch v. Squires, 105 Vt. 405, 165 Atl. 919 (1933).

235 Welsh v. James, 408 II. 18, 95 N.E.2d 872 (1950).

230 In re Edwards Estate, 140 Ore. 431, 14 P.2d 274 (1932). The cases cited in this discussion are illustrative only, and the citations do not purport to be inclusive. However, the law in all the states was examined, except in Louisiana. The Louisiana court, in a joint bank account controversy, stated that, "Rules governing the common law relation of joint tenancy has no application to a case of this character arising in this state. Ownership of property, real or personal, in this state, may arise only in the manner expressly established and recognized by its laws ...." Northcott v. Iivingood, 10 So.2d 401, 405 (La. App. 1942). 
that goes into the account but also because the account is opened for the purpose of accomplishing specified purposes. If he intends to create an agency account he wants the co-depositor to have the right to make withdrawals, although he does not contemplate that the survivor shall be entitled to the balance remaining in the account. On the other hand, if the party furnishing the funds intends to create a survivorship account, it is his wish that the survivor receive any funds that have not been dispersed during his lifetime. A depositor who opens such an account ought to be able to know, with some degree of certainty, that certain consequences will arise fron the creation of the account in an established manner.

To the extent that a joint deposit is a gift of a partial interest, which reduces the assets of the depositor and increases the funds of the donee, the creditors of both of the parties to the joint account are interested in the legal consequences that result from the transaction. Again, in this instance, there is need for sone established rule for ascertaining the proportion of the account that will be subject to the debts of either party. The cases are not clear on this point, and legislative clarification is required.

Not the least important consideration is the interest of the state, which determines the conditions under which its citizens may transfer their property. If the joint bank account is a new method of disposing of property, it should be recognized and controlled as such. The state also has an interest in its desire to reduce litigation. If controversies, arising from the uncertain status of the joint bank account, can be minimized by the adoption of more adequate laws, the legislature should do so.

\section{The Joint Bank Account-A New Concept}

Throughout this discussion there have been repeated references to the fact that the joint accounts do not fit into any of the common law categories for transferring property. The joint bank account does not qualify as a common law gift, because the donor does not surrender dominion. It is not a trust, because there is no intention on the part of the depositor to enter into such relationship. Neither is it a common law joint tenancy, because the four umities essential for creating this joint interest are lacking. While the parties may enter into a contract providing for the payment of the funds, the contract itself does not operate as a conveyance of the funds from one joint payee to the other joint payee. It is not a will, because it does not comply with the statutory formalities.

The joint and survivorship bank account transaction is a combination of all of the methods of transferring property listed in the preceding paragraphs. It partakes of the nature of a gift because it is gratuitous. It is like a will in that the beneficiary is not certain of the amount of the donation until the depositor's death. It is similar to a joint tenancy because of the 
creation of jomt interests. It has some of the characteristics of a revocable trust. Since the joint account combines in part the features of gifts, wills, joint tenancies and revocable trusts it is a new concept possessing independent characteristics of its own. It should be recogmized as such.

\section{Need for Legislative Reform}

While the cases pertaining to joint and survivorship bank accounts cannot be reconciled because of the different theories advanced in explanation of the transaction this is not the sole reason for the confusion in the law. Another cause for the misunderstanding is the fact that the legislation on this point is in three levels of development. At the first level are the states having the bank protection type statute. The jurisdictions that have enacted the joint tenancy joint bank account statutes represent the second stage. The most advanced type, or the third level, is the legislation which protects the bank and authorizes payment to the survivors, and also determines the rights annong other claimants to the fund.

Not realizing the basic difference in the statutory law of other states, courts have followed cases based on an entirely different type of legislation. The result is more confusion.

There is no question but that the joint and survivorship bank account will continue as a recognized ineans of transferring property. Legislation needs to be adopted which will not only define the nature of this new concept, but which will also establish the rights of all claimants to the fund. Since bank accounts serve substantially the same purpose in all jurisdictions, the statutes ought to be uniform.

In conclusion, the following model uniform Act is proposed:

\section{Model Joint Bank Account Statute}

Section 1. This act shall be known as the Joint Bank Account Gift Law.

Section 2. A deposit made in any banking institution doing business in this state, in the naines of two or more persons and payable to either or the survivor, may be paid to either during their joint lives and to the survivor upon the death of either. The receipt or acquittance of the person so paid shall be a valid release and discharge to the bank for any payment so made.

Section 3. The opening of the account in joint and survivorship form, upon written application of the depositor, witnessed by an officer or authorized employee of the bank, shall in the absence of fraud, undue influence or lack of mental capacity on the part of the depositor, be conclusive evidence of the depositor's intention to make a gift to the survivor of the balance remaining in the account at the depositor's death.

Section 4. The person furnishing the funds for the account may withdraw any of such funds during his lifetime, free from any claims of the co- 
depositor, except such claims that may arise by reason of a rule of law other than expressed in this act.

Section 5. Deposits in a joint and survivorship account shall be subject to the debts of either party to the extent that such depositor has contributed to the account.

Section 6. A joint and survivorship account is not severed by a judicial declaration of incompetency. A guardian of either of the parties inay withdraw from the account up to the total amount that his ward has contributed to the account; provided such funds are needed for the ward's maintenance; and provided further that the ward has no other property that may be used without causing hardship to a spouse, parent, brother or sister or other person dependent upon the ward for support.

Section 7. For the purpose of determining the statutory rights of a surviving spouse, any funds that shall pass to the survivor upon the death of the party furnishing the funds shall be treated as though the survivor acquired the balance of a specific devise in the depositor's will.

Section 8. A deposit made in the name of two persons, payable to either, but which makes no provision for survivorship, may be paid to either until the death of the depositor, and thereafter to the depositor's estate. The receipt or acquittance of the person so paid shall be a valid release and discharge to the bank for any payment so made, provided such payment is made before the receipt of a written notice from the depositor or a legal representative of his estate notifying the bank not to pay.

Section 9. The opening of the account in joint form without a provision for survivorship shall be conclusive evidence, in the absence of fraud or mistake, of the depositor's intention to open the account for his convenience only, and not for the purpose of making a gift to the co-depositor. The funds shall belong exclusively to the depositor, subject only to claims arising under other rules of law. Nothing contained in this section shall prohibit a reformation of the account upon a showing of fraud or mistake.

Section 10. The law shall apply to all accounts opened subsequent to its adoption. A depositor may subject an account opened prior to the date of this law to the provisions of this act by executing a new signature card, witnessed by an officer or authorized employee, on any day after the adoption of this law.

Section 11. All laws inconsistent with the provisions of this act are hereby repealed.

Section 12 . This act shall become effective immediately. 